
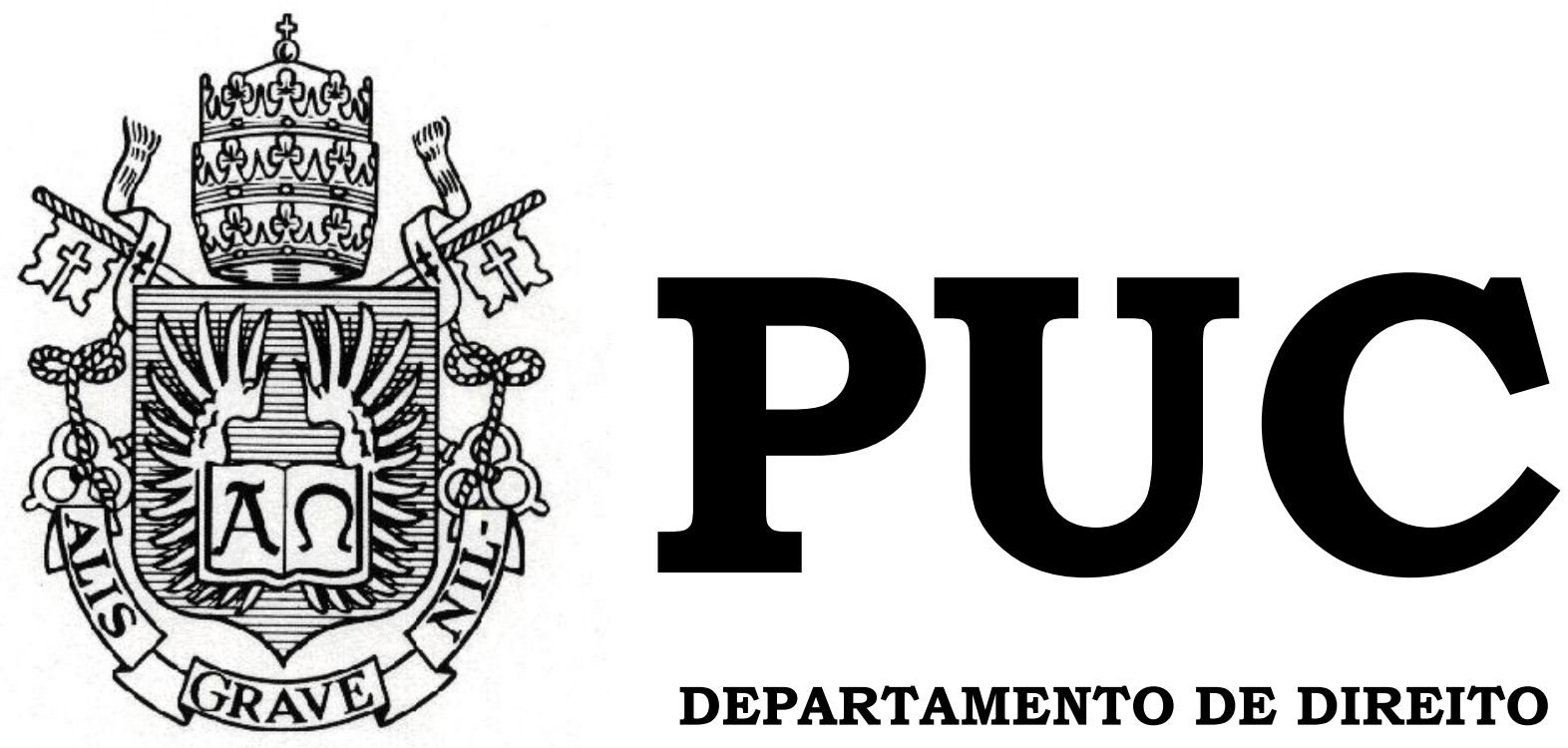

DEPARTAMENTO DE DIREITO

\title{
A APROXIMAÇÃO DO CONTROLE DIFUSO AO CONTROLE CONCENTRADO E A TEORIA DA ABSTRATIVIZAÇÃO
}

Por

Maria Luisa de Magalhães Barbosa

ORIENTADOR: Leonardo Moreira Lima

2012.2

PONTIFÍCIA UNIVERSIDADE CATÓLICA DO RIO DE JANEIRO RUA MARQUÊS DE SÃO VICENTE, 225 - CEP 22453-900 RIO DE JANEIRO - BRASIL 


\title{
A APROXIMAÇÃO DO CONTROLE DIFUSO AO CONTROLE \\ CONCENTRADO E A TEORIA DA \\ ABSTRATIVIZAÇÃO
}

\author{
Por \\ Maria Luisa de Magalhães Barbosa
}

Monografia

apresentada

ao

Departamento

de Direito

da

Pontificia Universidade Católica do Rio de Janeiro (PUC-Rio) para a obtenção do Título de Bacharel em Direito.

Orientador: Leonardo Moreira Lima 


\section{Agradecimentos}

Inicialmente, agradeço pelas excelentes aulas de jurisdição constitucional da Prof. a Marianna Montebello, que despertaram o meu interesse pelo tema.

Em seguida, ao Prof. Leonardo Moreira Lima, por ter aceitado me orientar neste trabalho e pelas sugestões.

Devo gratidão, também, a todos os profissionais com quem tive a oportunidade de trabalhar em meus estágios, pelas lições e exemplos, que me agregaram experiência e contribuíram para que eu chegasse mais madura até aqui. Desde a Defensoria Pública, passando pelo Lobo\&Ibeas Advogados, até a Procuradoria Geral do Estado. Neste particular, sou grata ao Procurador do Estado André Cyrino, que, apesar do pouco tempo de convívio, foi um chefe e tanto, por quem tenho imensa admiração profissional.

À minha família, vó, pais, irmão e irmãs, pelo apoio, torcida e confiança de sempre. Merece um agradecimento especial a minha irmã, Lígia, que, durante esses cinco anos, tem ouvido pacientemente muitos dos meus questionamentos jurídicos.

Por fim, às minhas amigas-irmãs, queridas, que estão sempre ao meu lado, desde os tempos de Colégio Santo Inácio, garantindo diversão e descontração em qualquer momento. À amiga de toda a vida e companheira de profissão, Karina, reservo um carinhoso "muito obrigada", por compartilhar de cada momento da minha caminhada até aqui, incansável nos incentivos e na motivação! 


\title{
Resumo
}

O presente trabalho tem como objetivo trazer aos leitores um panorama geral sobre a crescente aproximação entre os modelos de controle de constitucionalidade no Brasil e sobre a teoria da abstrativização do controle difuso-incidental no âmbito do Supremo Tribunal Federal. São analisados os principais motivos, apontados pelos adeptos da teoria, em defesa de sua consolidação, os mecanismos legislativos e jurisprudenciais gradativamente inseridos na realidade jurídica brasileira e que evidenciam a aproximação entre os dois modelos de controle, os efeitos decorrentes dessa aproximação e de eventual equiparação e as críticas que lhes são dirigidas.

\section{Palavras-chave}

\author{
Abstrativização \\ Controle de constitucionalidade \\ Controle difuso-incidental \\ Constituição Federal \\ Efeito vinculante \\ Eficácia erga omnes \\ Supremo Tribunal Federal
}




\section{Sumário}

Introdução

09

\section{Capítulo 1 - A Teoria da Abstrativização}

1.1. Noções sobre o controle de constitucionalidade .............................. 11

1.1.1. Pressupostos .................................................................. 11

1.1.2. Controle difuso e controle concentrado .................................... 12

1.1.3. Controle incidental e controle principal.................................... 12

1.2. O modelo brasileiro ...................................................................... 14

1.3. A teoria da abstrativização do controle difuso-incidental .................. 16

1.3.1. Introdução do modelo concentrado e a ênfase a ele conferida pela

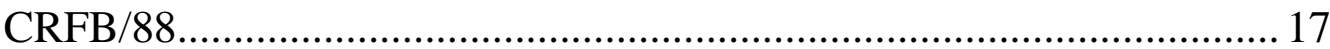

1.3.2. Potencialização de princípios constitucionais: isonomia e segurança jurídica, economia, efetividade e celeridade processuais ......20

1.3.3. Preservação da força normativa da Constituição ........................ 22

\section{Capítulo 2 - Mecanismos de Aproximação dos Modelos de Controle}

2.1. A relevância conferida à jurisprudência do STF pelos diplomas normativos

2.1.1. Poderes monocráticos do relator .............................................. 24

2.1.2. Dispensa de reexame necessário ................................................. 25

2.1.3. Súmula impeditiva de recursos ............................................. 25

2.1.4. Repercussão geral........................................................... 27

2.1.5. Sistemática de julgamento de recursos repetitivos .................... 29

2.2. Supressão do princípio da reserva de plenário .................................. 31

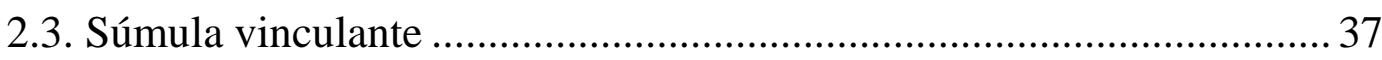

2.4. Os entendimentos jurisprudenciais ................................................. 42 
2.4.1. Modulação dos efeitos da decisão 42

2.4.2. Manifesta improcedência de ADI diante de precedente em RE ... 46

2.4.3. Efeitos erga omnes e vinculantes atribuídos pelo STF às suas

decisões em controle difuso-incidental 47

2.4.3.1. Eficácia transcendente da fundamentação 47

2.4.3.1.1. RE 197.917/SP e ADIs 3.345/DF e 3.365/DF........ 48

2.4.3.1.2. MIs 670/ES, 708/DF e 712/PA ............................. 50

2.4.3.1.3. HC 82.959/SP e Rcl 4.335/AC ............................ 52

\section{Capítulo 3 - Efeitos}

3.1. Redefinição do modelo de controle de constitucionalidade brasileiro. 55

3.1.1. Papel do Senado Federal: mutação constitucional? 55

3.1.2. Recurso extraordinário:controle abstrato disponível ao cidadão?.60

3.2. Ampliação do uso da Reclamação 61

3.3. Impactos sobre a coisa julgada 65

\section{Capítulo 4 - Críticas}

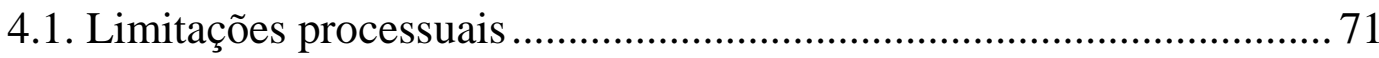

4.2. Concentração de poderes no STF, engessamento do direito e ameaça à

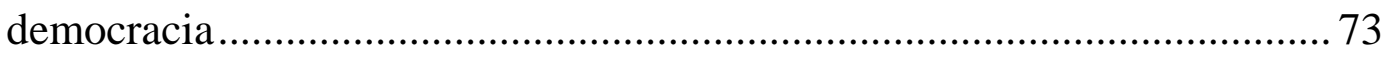

4.3. Agravamento da dificuldade contramajoritária................................ 79

4.4. Lesão a direitos fundamentais ..................................................... 82

4.5. A existência da súmula vinculante ................................................ 83

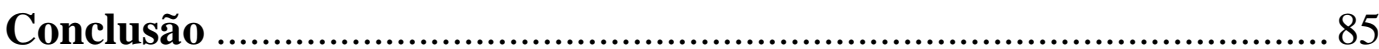

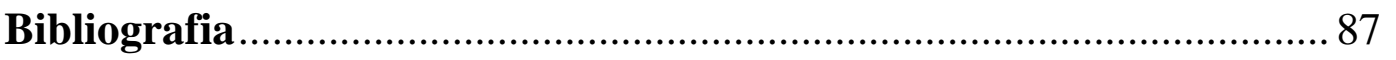




\section{Abreviações}

ADC - Ação Declaratória de Constitucionalidade

ADI - Ação Direta de Inconstitucionalidade

ADIO - Ação Direta de Inconstitucionalidade por Omissão

AGU - Advocacia Geral da União

CPC - Código de Processo Civil

CRFB - Constituição da República Federativa do Brasil

EC - Emenda Constitucional

HC - Habeas Corpus

MI - Mandado de Injunção

PGFN - Procuradoria Geral da Fazenda Nacional

RCL - Reclamação Constitucional

RE - Recurso Extraordinário

STF - Supremo Tribunal Federal

TSE - Tribunal Superior Eleitoral 


\section{Introdução}

Nos últimos anos, vem se percebendo uma crescente aproximação entre os dois modelos de controle de constitucionalidade na realidade jurídica brasileira. Nesse contexto, fortaleceu-se a teoria da abstrativização do controle difuso-incidental, que pode ser definida como a pretensão de se equiparar os efeitos desse modelo de controle aos efeitos do controle concentrado-principal. Busca-se, através dela, conferir eficácia erga omnes e vinculante automática às decisões do Supremo Tribunal Federal, proferidas no exame de casos concretos.

Não se olvida de que se trata de tema extremamente complexo, a afetar diversos institutos há muito consolidados no ordenamento jurídico pátrio. Por isso, ressalta-se, desde já, que o presente estudo não tem como pretensão esgotar o objeto em análise. $\mathrm{O}$ que se pretende é fazer uma exposição consistente sobre a aproximação entre os dois modelos de controle no direito brasileiro, trazendo os fundamentos que legitimariam eventual equiparação, os mecanismos inseridos de modo a conferir força generalizante às decisões do STF, os efeitos dessa aproximação e da possível consolidação da teoria da abstrativização, bem como as críticas que lhe são dirigidas. Desse modo, visa-se proporcionar a reflexão dos leitores acerca do assunto.

É pertinente esclarecer, ainda, que este trabalho monográfico detémse à análise da teoria da abstrativização aplicada ao controle difusoincidental de leis e atos normativos, ainda que o objeto do controle de constitucionalidade seja mais amplo. Assim se optou porque o intuito primordial é a comparação aos efeitos produzidos em ações diretas de constitucionalidade, as quais, exceto pela ADPF, têm como objeto apenas atos do Poder Público de conteúdo normativo.

No primeiro capítulo, trazem-se noções gerais sobre o controle de constitucionalidade e sobre o modelo híbrido implantado no Brasil, com a 
convivência simultânea das duas formas tradicionais de controle. Analisamse, a partir daí, os principais motivos que vêm levando parte da doutrina e da jurisprudência a sustentar não só a aproximação como a equiparação dos efeitos produzidos no controle difuso-incidental àqueles produzidos em ações diretas, quando a decisão seja prolatada pelo Supremo Tribunal Federal.

No segundo capítulo, expõem-se alguns dos diversos mecanismos gradativamente inseridos, pela legislação e pela jurisprudência, de forma a conferir efeitos generalizantes e, às vezes, vinculantes às decisões da Suprema Corte. Destarte, demonstra-se como tais instrumentos evidenciam uma inclinação à aproximação entre os dois modelos de controle e contribuem para fundamentar a teoria da abstrativização do controle difusoincidental.

Em seguida, no terceiro capítulo, examinam-se os efeitos que aludida aproximação - e eventual equiparação - produz e pode vir a produzir em alguns institutos estabilizados no ordenamento jurídico brasileiro, o que denota a sua força transformadora.

Por fim, no quarto e último capítulo, procura-se trazer as principais críticas direcionadas tanto a alguns dos mecanismos já implantados como à pretensão de se efetivar a completa igualação entre os efeitos dos dois modelos de controle de constitucionalidade. Quer-se, assim, estimular o pensamento crítico dos leitores, induzindo-os a um exercício de ponderação entre as vantagens e desvantagens da abstrativização do controle difusoincidental. 


\section{Capítulo 1}

\section{A Teoria da Abstrativização}

\subsection{Noções sobre o controle de constitucionalidade}

\subsubsection{Pressupostos}

O controle de constitucionalidade é um mecanismo criado pelo legislador constituinte para aferição da compatibilidade dos atos normativos infraconstitucionais com a Constituição. Conforme ensina Luís Roberto Barroso, só é possível se falar em controle de constitucionalidade se presentes dois pressupostos: a supremacia e a rigidez constitucionais. ${ }^{1}$

A supremacia da Constituição revela a sua posição hierárquica mais elevada em relação às demais normas do ordenamento jurídico, posicionando-se a Lei Maior no "ápice da pirâmide"2. Funciona, por isso, como fundamento de validade de todos os atos infraconstitucionais.

Já a rigidez constitucional significa que a norma constitucional observa processo de elaboração mais complexo do que as demais normas do sistema. Tal característica é essencial para que se distinga objeto de controle (normas infraconstitucionais) e parâmetro de controle (normas constitucionais). Na ausência dessa distinção, a cada vez que uma norma infraconstitucional fosse editada, em contrariedade a uma norma constitucional, esta última seria revogada. ${ }^{3}$

Alguns autores elegem, também, como pressuposto do controle de constitucionalidade, a existência de um órgão com a atribuição de analisar a

\footnotetext{
${ }^{1}$ BARROSO, Luís Roberto. O controle de constitucionalidade no direito brasileiro. $6^{\mathrm{a}}$ ed. São Paulo: Saraiva, 2012. p. 23

${ }^{2}$ LENZA, Pedro. Direito constitucional esquematizado. $13^{\mathrm{a}}$ ed. São Paulo: Saraiva, 2009. p. 150

${ }^{3}$ BARROSO, Luís Roberto. Op. cit., p. 24
} 
compatibilidade das leis e atos normativos com a Constituição, órgão este que variará conforme o sistema de controle adotado. ${ }^{4}$

\subsubsection{Controle difuso e controle concentrado}

De acordo com o órgão judicial que exerce o controle de constitucionalidade, poderá ele ser classificado como difuso ou concentrado. O controle é difuso quando a todo juiz ou tribunal é dado conhecer a incompatibilidade de uma norma com a Constituição. Por outro lado, diz-se que o controle é concentrado quando a apenas um ou a poucos órgão judiciais é atribuída essa função.

\subsubsection{Controle incidental e controle principal}

Outra classificação muito utilizada refere-se ao modo como é exercido o controle de constitucionalidade, podendo ocorrer via incidental ou via principal.

O controle exercido incidentalmente é aquele em que a questão constitucional surge como questão prejudicial no curso de um processo subjetivo, podendo ser alegada por qualquer das partes e servindo de premissa lógica para a resolução do pedido principal. Por isso, a decisão do incidente de inconstitucionalidade incorpora-se necessariamente à fundamentação da decisão final e não ao seu dispositivo. Assim é que, convencionalmente, os efeitos da decisão do incidente ficam restritos às partes que compõem o processo principal.

Em contrapartida, no controle exercido por meio de ação direta, a questão constitucional constitui o objeto principal do processo, estando, em regra, desvinculada de um caso concreto em que haja disputa entre partes. Presta-se, em verdade, a preservar a higidez do ordenamento jurídico e não à tutela de direitos subjetivos. Logo, na medida em que a declaração de

\footnotetext{
${ }^{4}$ LENZA, Pedro. Op. cit., p. 149
} 
inconstitucionalidade constitui o próprio objeto da ação, a sua consequência será a extirpação da norma impugnada do ordenamento jurídico. Por conseguinte, os efeitos dessa decisão atingirão a toda e qualquer pessoa que a tal norma estiver submetida. A resolução da questão constitucional produz, portanto, efeitos erga omnes e vinculantes, o que, hoje, está expresso no art. $102, \S 2^{\circ}, \mathrm{CRFB}^{5}$

Por decorrer de um caso concreto levado a juízo - sobre o qual repercutirão os efeitos da resolução da questão constitucional -, o controle incidental costuma também ser chamado de controle concreto. Já o controle principal, na medida em que exsurge de um processo objetivo, em que a questão constitucional é posta em tese, é comumente referido como controle abstrato. Entretanto, não há uma necessária correlação entre essas classificações. É possível que o controle seja incidental, mas a análise da questão constitucional seja feita em abstrato, fator que adquire especial importância para o tema tratado no presente trabalho. Igualmente, pode o controle ser principal, mas referir-se a um caso concreto. É a hipótese, por exemplo, da ação direta interventiva, prevista em nosso ordenamento jurídico. Nela, em que pese o exercício do controle de constitucionalidade ocorrer via ação direta, a declaração do STF produz efeitos para o caso concreto, o da intervenção que se pretende realizar. ${ }^{6}$

Tampouco há obrigatoriedade de que o controle incidental seja exercido de modo difuso ou que o controle principal seja exercido de modo concentrado, ainda que no direito brasileiro seja essa a forma adotada. Em muitos países europeus, por exemplo, o controle é incidental e concentrado: estando presente questão constitucional, o processo é suspenso pelo juiz da causa e a questão submetida diretamente ao Tribunal Constitucional.

Registre-se, ainda nesse tópico, que, para alguns autores, é diminuta a relevância teórica da distinção entre controle incidental e controle

\footnotetext{
${ }^{5}$ CRFB, art. 102, $2^{\circ}$ : "As decisões definitivas de mérito, proferidas pelo Supremo Tribunal Federal, nas ações diretas de inconstitucionalidade e nas ações declaratórias de constitucionalidade produzirão eficácia contra todos e efeito vinculante, relativamente aos demais órgãos do Poder Judiciário e à administração pública direta e indireta, nas esferas federal, estadual e municipal".

${ }^{6}$ Exemplo retirado da obra de Luís Roberto Barroso. BARROSO, Luís Roberto. Op. cit., p. 73.
} 
principal. Isto porque, o incidente de inconstitucionalidade, surgido no julgamento do caso concreto, assumiria sempre contornos abstratos, eis que seu processamento se realiza de forma independente do feito do qual se originou. $^{7}$

\subsection{O modelo brasileiro}

Em sua origem, o controle de constitucionalidade brasileiro sofreu influência do modelo norte-americano, tendo sido introduzido, na Constituição de 1891, o critério de controle difuso e incidental, que perdura até os dias atuais.

A Constituição de 1934 instituiu a cláusula da reserva de plenário, exigindo a obtenção de voto da maioria absoluta dos membros dos tribunais para que se declarasse a inconstitucionalidade de uma norma. ${ }^{8}$

Do mesmo modo, previu-se a competência privativa do Senado Federal para suspender a norma declarada inconstitucional por decisão definitiva do STF. Essa atribuição consta do art. 52, X da Constituição vigente. ${ }^{9}$ Percebe-se que, já àquela época, introduzia-se um mecanismo de abstrativização do controle difuso-incidental. Visava-se, com a suspensão senatorial, conferir efeitos erga omnes à declaração de inconstitucionalidade proferida incidentalmente pelo STF. ${ }^{10}$

\footnotetext{
${ }^{7}$ Nesse sentido, Gilmar Mendes: "Schlaich ressalta a equivocidade desses conceitos, porquanto o controle realizado, a decisão proferida e as consequências jurídicas são verdadeiramente abstratas, na medida em que se processam independentemente do feito originário. Em outros termos, o controle e o julgamento levados a efeito pelo tribunal estão plenamente desvinculados do processo originário, tendo, por isso, consequências jurídicas idênticas". MENDES, Gilmar Ferreira et al. Curso de Direito Constitucional. $4^{\mathrm{a}}$ ed. São Paulo: Saraiva, 2009. p. 1115

${ }^{8}$ A mesma previsão repetiu-se nas Constituições posteriores, encontrando-se no art. 97 da Carta atual. "Art. 97. Somente pelo voto da maioria absoluta de seus membros ou dos membros do respectivo órgão especial poderão os Tribunais declarar a inconstitucionalidade de lei ou ato normativo do Poder Público". O fundamento da cláusula da reserva de plenário é o princípio de presunção de constitucionalidade das leis, sendo necessário, para desconstituí-la, um quórum qualificado.

${ }^{9}$ CRFB, art. 52, X: "Compete privativamente ao Senado Federal: suspender a execução no todo ou em parte, de lei declarada inconstitucional por decisão definitiva do Supremo Tribunal Federal".

${ }^{10}$ Discussão importante acerca desse ponto e relacionada ao objeto deste trabalho será exposta no Capítulo 3. Refere-se às razões da atribuição, ao Senado Federal, de suspensão da norma incidentalmente declarada inconstitucional.
} 
Em 1965, com a Emenda Constitucional n. 16/65, o sistema de controle concentrado e principal passou a integrar, também, o modelo de controle de constitucionalidade brasileiro. Foi prevista a representação de inconstitucionalidade, de iniciativa privativa do Procurador Geral da República. Nada obstante, como bem asseverado por Gilmar Mendes, "a ação direta subsistiu como elemento acidental no âmbito de um sistema difuso predominante". ${ }^{11}$

Esse quadro modificou-se sobremaneira com a Constituição de 1988, que teve como principal inovação pôr fim ao monopólio do Procurador Geral da República em relação à propositura de ação direta de inconstitucionalidade, ampliando significativamente o rol de legitimados. ${ }^{12}$ A Carta atual alargou, ainda mais, o papel do controle concentradoprincipal ao prever a ação direta de inconstitucionalidade por omissão ${ }^{13}$ e a arguição de descumprimento de preceito fundamental. ${ }^{14}$ Mais tarde, a EC n. 3/93 criou, também, a ação declaratória de constitucionalidade. ${ }^{15}$

Vê-se, portanto, que, desde 1965, o controle de constitucionalidade brasileiro apresenta um modelo híbrido, em que convivem, simultaneamente, o controle difuso-incidental e o controle concentradoprincipal.

\footnotetext{
${ }^{11}$ MENDES, Gilmar Ferreira et al. Curso de Direito Constitucional. $4^{\mathrm{a}}$ ed. São Paulo: Saraiva, 2009. p. 1111

${ }^{12}$ CRFB, art. 103, caput: "Podem propor a ação direta de inconstitucionalidade e a ação declaratória de constitucionalidade: I - o Presidente da República; II - a Mesa do Senado Federal; III - a Mesa da Câmara dos Deputados; IV - a Mesa de Assembleia Legislativa ou da Câmara Legislativa do Distrito Federal; V - o Governador de Estado ou do Distrito Federal; VI - o Procurador-Geral da República; VII - o Conselho Federal da Ordem dos Advogados do Brasil; VIII - partido político com representação no Congresso Nacional; IX - confederação sindical ou entidade de classe de âmbito nacional".

${ }^{13}$ CRFB, art. 103, $\$ 2^{\circ}$ : "Declarada a inconstitucionalidade por omissão de medida para tornar efetiva norma constitucional, será dada ciência ao Poder competente para a adoção das providências necessárias e, em se tratando de órgão administrativo, para fazê-lo em trinta dias".

${ }^{14} \mathrm{CRFB}$, art. 102, $\S 1^{\circ}$ : "A arguição de descumprimento de preceito fundamental decorrente desta Constituição será apreciada pelo Supremo Tribunal Federal, na forma da lei".

${ }^{15}$ CRFB, art. 102: "Compete ao Supremo Tribunal Federal, precipuamente, a guarda da Constituição, cabendo-lhe: I - processar e julgar, originariamente: a) a ação direta de inconstitucionalidade de lei ou ato normativo federal ou estadual e a ação declaratória de constitucionalidade de lei ou ato normativo federal;"
} 
Aspecto relevante a ser destacado é que, no Brasil, consolidou-se a teoria da nulidade da norma inconstitucional. ${ }^{16} \mathrm{O}$ raciocínio guarda coerência com o princípio da supremacia da Constituição, na medida em que, admitir que uma norma inconstitucional tenha produzido efeitos válidos durante determinado período, seria negar vigência a Lei Maior nesse interregno. Isso jogaria por terra um dos pressupostos sobre o qual se assenta o controle de constitucionalidade. Por conseguinte, a decisão que reconhece a inconstitucionalidade de uma lei ou ato normativo possui natureza declaratória, retroagindo os seus efeitos para atingir todas as relações constituídas sob a égide do ato viciado. Como regra geral, esse efeito retroativo poderá ser erga omnes ou inter partes, dependendo da via de controle.

Todavia, a teoria da nulidade da norma inconstitucional sofre alguns temperamentos decorrentes da ponderação do princípio da nulidade com princípios igualmente protegidos pela Constituição como, por exemplo, a segurança jurídica e a boa-fé. Essa modulação dos efeitos da decisão está, inclusive, positivada no art. 27 da Lei 9.868/99 ${ }^{17}$. Outras técnicas que podem ser citadas como atenuantes à teoria da nulidade são a interpretação conforme a Constituição e a declaração de inconstitucionalidade sem redução de texto, uma vez que a norma permanece intacta no ordenamento jurídico.

\subsection{A teoria da abstrativização do controle difuso-incidental}

Conforme acima mencionado, já existia, desde a Constituição de 1934, mecanismo apto à atribuição de efeitos erga omnes às decisões

\footnotetext{
${ }^{16}$ Em que pese doutrina minoritária em sentido contrário, como, conforme destacado por Pedro Lenza, é o caso de Pontes de Miranda e Regina Nery Ferrari. LENZA, Pedro. Op. cit., p. 151.

${ }^{17}$ Lei 9.868/99, art. 27: "Ao declarar a inconstitucionalidade de lei ou ato normativo, e tendo em vista razões de segurança jurídica ou de excepcional interesse social, poderá o Supremo Tribunal Federal, por maioria de dois terços de seus membros, restringir os efeitos daquela declaração ou decidir que ela só tenha eficácia a partir de seu trânsito em julgado ou de outro momento que venha a ser fixado."
} 
proferidas pelo STF em controle difuso-incidental: a suspensão, pelo Senado Federal, da norma declarada inconstitucional. No entanto, nos últimos anos, tem-se observado a tendência de que tal efeito seja produzido por outras vias, sem a participação do Senado. Nesse contexto, fortaleceu-se a ideia de proceder-se a uma completa equiparação entre os dois modelos de controle de constitucionalidade, conferindo-se efeitos erga omnes e vinculantes automáticos às decisões do STF no exame de casos concretos. Tal fenômeno foi denominado, pela doutrina, de abstrativização do controle difuso-incidental de constitucionalidade. ${ }^{18}$ A seguir, analisaremos alguns dos motivos, apontados por reconhecidos juristas, para o fortalecimento dessa teoria.

\subsubsection{Introdução do modelo concentrado e ênfase a ele conferida pela CRFB/88}

A simples inauguração, no Brasil, do modelo de controle concentrado-principal já contribuiu, em alguma medida, para diminuir a participação do Senado na extensão dos efeitos das decisões de inconstitucionalidade proferidas pelo STF. A EC n. 16/65 introduziu, ainda que de forma tímida, modelo pelo qual a Corte não mais dependia da atuação da Casa Legislativa para fazer valer, perante todos, a sua decisão.

Mas foi com a Carta de 1988, como já brevemente exposto, que o controle concentrado-principal passou a ocupar posição de revelo em nosso ordenamento jurídico. Com um rol de legitimados de alta representatividade e novos contornos dados à ação direta, o modelo se expandiu. Em contrapartida, o controle difuso-incidental perdeu a predominância que até então apresentava.

Em síntese que bem demonstra essa mudança de centro, pronunciouse Gilmar Mendes:

\footnotetext{
18 O fenômeno da abstrativização é também chamado, por alguns autores, de abstração, objetivação, objetivização, dessubjetivização ou centralização do controle difuso-incidental.
} 


\begin{abstract}
"Assim, se se cogitava, no período anterior a 1988, de um modelo misto de controle de constitucionalidade, é certo que o forte acento residia, ainda, no amplo e dominante sistema difuso de controle. O controle direto continuava a ser algo acidental e episódico dentro do sistema difuso.

A Constituição de 1988 alterou, de maneira radical, essa situação, conferindo ênfase não mais ao sistema difuso ou incidental, mas ao modelo concentrado, uma vez que as questões constitucionais passaram a ser veiculadas, fundamentalmente, mediante ação direta de inconstitucionalidade perante o Supremo Tribunal Federal.

(...)

A ampla legitimação, a presteza e a celeridade desse modelo processual, dotado inclusive da possibilidade de se suspender imediatamente a eficácia do ato normativo questionado, mediante pedido de cautelar, fazem com que as grandes questões constitucionais sejam solvidas, na sua maioria, mediante a utilização da ação direta, típico instrumento do controle concentrado. Assim, se continuamos a ter um modelo misto de controle de constitucionalidade, a ênfase passou a residir não mais no sistema difuso, mas no de perfil concentrado."19
\end{abstract}

De fato, a partir da Carta de 1988, além do Procurador Geral da República, passaram a ser também legitimados, para a propositura de ação direta, o Presidente da República, as Mesas do Senado, da Câmara dos Deputados e das Assembleias Legislativas, o Governador do Estado, o Conselho Federal da $\mathrm{OAB}$, partido político com representação no Congresso Nacional e confederação sindical ou entidade de classe de âmbito nacional. Também foram introduzidos, além da ADI, já existente, outros meios para se provocar a jurisdição constitucional abstrata e concentrada, tais como a ADIO, a ADPF e, posteriormente, a ADC. ${ }^{20}$

Assim, se antes, pelo pouco número de impugnações via ação direta, dificilmente o STF tinha o poder de declarar uma inconstitucionalidade com efeitos erga omnes - revelando-se ainda importante a participação do Senado nessa atribuição -, com as alterações, trazidas pela Constituição de 1988, essa atuação da Suprema Corte tornou-se acessível e frequente.

\footnotetext{
${ }^{19}$ MENDES, Gilmar Ferreira. O papel do Senado Federal no Controle de Constitucionalidade: um caso clássico de mutação constitucional. Disponível em <http://www.direitopublico.idp.edu.br>. Acesso em 09 de julho de 2012.

${ }^{20}$ Importante efeito a ser destacado em relação a ADI e a ADC é que, julgada improcedente aquela ou procedente esta (ou seja, reconhecida a constitucionalidade da norma), a decisão não faz coisa julgada em relação ao STF, que continua a poder declarar, em eventual nova ação direta, a inconstitucionalidade da norma que julgara legitima. No entanto, a decisão faz coisa julgada e vincula todos os demais tribunais no exercício do controle difuso-incidental, de modo que ficam impedidos de declarar a inconstitucionalidade da norma, tendo de aplicá-la. Isso, decerto, reduz o papel do controle incidental, passando o STF a ficar com o "monopólio" do poder de declarar inconstitucional a norma. Por isso, a constitucionalidade da ADC é até mesmo questionada por alguns juristas.
} 
Consequentemente, hoje, ainda que o Senado não suspenda uma norma incidentalmente declarada inconstitucional, a questão pode chegar novamente à Corte, sem maiores óbices, de forma a serem obtidos aqueles efeitos.

Diante desse novo contexto, muitos autores começaram a defender que, se o próprio constituinte atribuíra ao Pleno do STF a possibilidade de decidir questões constitucionais com efeitos generalizantes automáticos, não haveria motivos para que não fossem conferidos os mesmos efeitos a decisões de idêntico teor, proferidas pelo mesmo órgão, mas em controle difuso-incidental.

Nessa linha, confiram-se os comentários de Luís Roberto Barroso:

"A verdade é que, com a criação da ação genérica de inconstitucionalidade, pela EC n. 16/65, e com o contorno dado à ação direta pela Constituição de 1988, essa competência atribuída ao Senado tornou-se um anacronismo (...). Seria uma demasia, uma violação ao princípio da economia processual, obrigar um dos legitimados do art. 103 a propor ação direta para se produzir uma decisão que já se sabe qual é!"21

No mesmo sentido, o entendimento de Sepúlveda Pertence, ao proferir voto na ADC 1:

"De tal modo, o peso do Supremo Tribunal, em relação aos outros órgãos de jurisdição, que a ação declaratória de constitucionalidade traz é relativo, porque, já no sistema de convivência dos dois métodos, a palavra final é sempre reservada ao Supremo Tribunal Federal, se bem que, declarada a inconstitucionalidade no sistema difuso, ainda convivamos com o anacronismo em que se transformou, especialmente após a criação da ação direta, a necessidade da deliberação do Senado para dar eficácia erga omnes à declaração incidente."22

Fica bastante claro, a partir disso, que a ênfase conferida ao controle concentrado-principal, por si só, gera questionamentos quanto à manutenção dos efeitos automáticos, apenas inter partes, no controle difuso-incidental. Com efeito, trata-se de um dos argumentos levantados por aqueles que defendem a abstrativização desse modelo de controle.

\footnotetext{
${ }^{21}$ BARROSO, Luís Roberto. Op. cit., p. 157-158

${ }^{22}$ MENDES, Gilmar Ferreira. O papel do Senado Federal no Controle de Constitucionalidade: um caso clássico de mutação constitucional. Op. cit., p. 20
} 


\subsubsection{Potencialização de princípios constitucionais: isonomia segurança jurídica, economia, efetividade e celeridade processuais}

É fato que a produção de efeitos somente entre as partes, em decisões emanadas em controle difuso-incidental, acarreta consequências que podem atingir, de forma grave, princípios consagrados pela própria Constituição. Um deles é a isonomia, tendo em vista que, enquanto a norma deixa de ser aplicada à situação jurídica levada a exame, permanece produzindo efeitos em relação a outras situações idênticas, não judicializadas. Isso força cada cidadão que queira ver o seu direito tutelado a buscar, de igual modo, a manifestação do Judiciário. Tal quadro, além de ferir a isonomia, tampouco se coadunaria com os princípios da economia, da efetividade e da celeridade processuais. Simultaneamente, ver-se-ia atingindo o princípio da segurança jurídica. Isto porque, mesmo havendo decisão do órgão de cúpula do Judiciário, a questão estaria ainda sujeita ao exame de diversos juízes e tribunais, podendo ser julgada constitucional num caso e inconstitucional no outro, até chegar novamente à apreciação da Suprema Corte em cada um desses processos.

Sabe-se, porém, que o Senado possui competência para solucionar esses problemas, através da suspensão da norma declarada inconstitucional. A crítica, no entanto, gira em torno de que, sendo essa uma competência discricionária $^{23}$, caso a casa legislativa se mantenha inerte, a decisão continua a ter efeitos meramente inter partes. E não seriam raros os casos em que isso ocorre. Diante disso, permanecem ameaçadas a isonomia, a segurança jurídica e a economia, a celeridade e a efetividade processuais.

Ademais, após a inauguração do controle concentrado no país, há que se considerar que a mesma questão pode ser novamente levada ao STF, por qualquer dos legitimados à ação direta, obtendo-se idêntica decisão com

\footnotetext{
23 Adota-se aqui o posicionamento consolidado da doutrina majoritária, no sentido de que a competência do Senado prevista no art. 52, $\mathrm{X}, \mathrm{CRFB}$ é ato político, constituindo discricionariedade da casa legislativa.
} 
efeitos erga omnes automáticos. Assim, adiar a produção de tais efeitos, obrigando nova provocação da Corte, esbarraria, novamente, nos mencionados princípios.

Sob essa perspectiva, faz-se oportuno transcrever trecho da obra de Teori Albino Zavascki, no qual conclui que as decisões do STF a respeito da constitucionalidade de uma norma devem, naturalmente, se expandir para além do caso concreto. Veja-se:

\begin{abstract}
"Assim, põe-se em foco, objetivamente, a questão de como harmonizar a eficácia da decisão sobre a constitucionalidade da norma no caso concreto com as imposições dos princípios constitucionais da isonomia - que é absolutamente incompatível com eventuais tratamentos diferentes em face da mesma lei quando forem idênticas as situações -, e da segurança jurídica, que recomenda o grau mais elevado possível de certeza e estabilidade dos comandos normativos. Há, ademais, uma razão de ordem prática: se a norma é aplicável a um número indefinido de situações, não faz sentido repetir, para cada uma delas, o mesmo julgamento sobre a questão constitucional já resolvida em oportunidade anterior. Essas são razões a demonstrar que as decisões a respeito da legitimidade das normas têm vocação natural para assumir uma projeção expansiva, para fora dos limites do caso concreto." 24
\end{abstract}

Bem se vê, dessa forma, que a potencialização desses princípios constitucionais é apontado, pelos adeptos da teoria da abstrativização, como mais um motivo na defesa de sua consolidação. ${ }^{25}$

\footnotetext{
${ }^{24}$ ZAVASCKI, Teori Albino. Eficácia das sentenças na jurisdição constitucional. Disponível em <http://www.lume.ufrgs.br>. Acesso em 11 de julho de 2012.

${ }^{25}$ Os precedentes judiciais que versam sobre mecanismos generalizantes dos efeitos das decisões do STF sempre apontam para a potencialização de princípios como a economia, a celeridade e a efetividade processuais ou a segurança jurídica e isonomia entre os jurisdicionados.

Também, nessa linha, posiciona-se parte da doutrina, conforme revelam os comentários de José Carlos Navarro de Almeida Prado sobre o assunto: "A abstrativização do controle de constitucionalidade no caso concreto ou controle difuso abstrativizado, segundo Fredie Didier Júnior, presta-se a atender, a um só tempo, ao jurisdicionado e ao Judiciário brasileiro. O primeiro vê atendida, ainda que de forma diminuta, o seu direito constitucional à celeridade processual, positivado no inciso LXXVIII do art. $5^{\circ}$ pela Emenda Constitucional n ${ }^{\circ} 45 / 04$, a chamada Reforma do Judiciário. Com efeito, o cidadão pode obter para si o benefício da declaração de inconstitucionalidade de um regramento em processo de terceiro, sem a necessidade de também dirigir-se ao Tribunal Maior ou aguardar o vetusto, burocrático e pouco ocorrente expediente de edição de resolução pelo Senado Federal, suspendendo os efeitos da lei declarada inconstitucional, como reza o inciso X do art. 52 da mesma Carta Republicana. Já o Judiciário, em especial o próprio colendo Supremo Tribunal Federal, pode se ver livre de milhares de expedientes de cunho idêntico, racionalizando o seu serviço, de sorte a abolir a ilógica necessidade de prolatar a mesma decisão em cada processo, o que transforma os onze ministros, representantes da cúpula judicante nacional, em despachantes judiciais ou carimbadores oficiais. Em suma, o Pacto de Estado por um Judiciário mais Rápido e Republicano, firmado entre os três Poderes e o Ministério Público, poderá, ao menos na Corte Maior, começar a sair do papel." Retirado de RODRIGUES, Lays
} 


\subsubsection{Preservação da força normativa da Constituição}

Outra premissa em que se assentaria a teoria da abstrativização do controle difuso-incidental é a preservação da força normativa da Constituição. ${ }^{26}$

A força normativa, desenvolvida por Konrad Hesse, é princípio que confere à Constituição máxima eficácia, devendo os seus preceitos ser efetivamente observados em todas as relações jurídicas que se desenvolvam.

Permitir que uma norma, já reconhecida inconstitucional pelo STF, ainda que incidenter tantum, continue a produzir efeitos seria, na visão de alguns autores, admitir a violação da Lei Maior em todos os casos que não aquele levado ao exame da Corte. Seria, pois, negar vigência ao princípio da supremacia da Constituição e, consequentemente, desprezar a sua força normativa.

Faria. A Tendência da Abstrativização do Controle Difuso de Constitucionalidade. Disponível em http://www.lfg.com.br. Acesso em 11 de julho de 2012.

26 Nesse sentido, veja-se trecho do voto do Min. Celso de Mello, no julgamento de improcedência das ADIs 3.345 e 3.365, que questionavam a constitucionalidade de Resolução do TSE, editada com base em julgado da Suprema Corte proferido em controle difuso. Sob a justificativa de submeter-se à força normativa da Constituição, o STF entendeu constitucional referida resolução, estendendo os efeitos daquele julgado: "Torna-se relevante enfatizar que o Tribunal Superior Eleitoral, como já referido, ao editar a resolução questionada, consubstanciadora de mera explicitação de anterior julgamento desta Suprema Corte, proferido em sede de controle incidental de constitucionalidade, limitou-se a agir em função de postulado essencial à valorização da própria ordem constitucional, cuja observância fez prevalecer, no plano do ordenamento positivo, a força normativa, a unidade e a supremacia da Lei Fundamental da República (...). Na realidade, o Tribunal Superior Eleitoral, expondo-se à eficácia irradiante dos motivos determinantes que fundamentaram o mencionado julgamento plenário do RE 197.917/SP, Rel. Min. Maurício Corrêa, submeteu-se, na elaboração do ato ora questionado, ao princípio da força normativa da Constituição, que representa diretriz relevante no processo de interpretação concretizante do texto constitucional." 


\section{Capítulo 2}

\section{Mecanismos de Aproximação dos Modelos de Controle}

\subsection{A relevância conferida à jurisprudência do STF pelos diplomas normativos}

Sem embargo das ponderações apontadas no capítulo anterior, o fato é que o constituinte originário manteve a fórmula de somente se conferir eficácia erga omnes e efeito vinculante às decisões incidentais, quando procedida a suspensão da norma pelo Senado.

Mas, face - entre outros motivos - à inoperância daquela Casa Legislativa e o assoberbamento do STF, foram sendo criados novos mecanismos, pela legislação, para se estender a terceiros os efeitos de decisões proferidas em controle difuso-incidental, independentemente da intervenção senatorial. Esses mecanismos, se não são suficientes para denotar uma efetiva equiparação entre os dois modelos de controle - uma vez que os efeitos generalizantes não se dão de modo automático -, ao menos, indicam uma aproximação entre eles. Por isso, representam forte argumento dos adeptos da teoria da abstrativização, que os encaram como prenúncio de sua consolidação.

Decerto, a análise de cada um destes mecanismos poderia render trabalho autônomo. O que se fará aqui é tão somente expor tais institutos, em linhas gerais, demonstrando como cada um acabou por conferir efeitos generalizantes a julgados do STF que, originariamente, teriam efeitos meramente inter partes. 


\title{
2.1.1. Poderes monocráticos do relator
}

A Lei 9.756/98, alterando o caput do art. 557, $\mathrm{CPC}^{27}$ e nele introduzindo o $\S 1^{\circ}-\mathrm{A}^{28}$, conferiu, ao relator, poder de negar ou dar provimento a recurso, monocraticamente, conforme a decisão recorrida esteja ou não em consonância com a jurisprudência consolidada do STF.

Em uma interpretação conjunta com o art. 481, parágrafo único, CPC (tratado com maiores detalhes no tópico 2.2 deste Capítulo), isso significa que, havendo decisão da Suprema Corte em incidente de inconstitucionalidade, esse precedente poderá ser invocado pelo relator para deferir ou indeferir, de plano, o recurso.

É o que se extrai de alguns julgados do STF, como o cuja ementa se segue: $:^{29}$

\begin{abstract}
"EMENTA: PROCESSUAL CIVIL. AGRAVO REGIMENTAL. CONTROLE DE CONSTITUCIONALIDADE. RESERVA DE PLENÁRIO PARA DECLARAÇÃO DE INCONSTITUCIONALIDADE DE LEI. ART. 97 DA CONSTITUIÇÃO. INOBSERVÂNCIA. IRRELEVÂNCIA. TESE DE FUNDO SEDIMENTADA EM SENTIDO CONTRÁRIO AO POSTULADO PELA PARTE-AGRAVANTE. A REFORMA DO ACÓRDÃO PARA PROLAÇÃO DE NOVA DECISÃO NÃO IMPLICARIA REVERSÃO DO JULGADO. TRIBUTÁRIO. FINSOCIAL. AUMENTOS DE ALÍQUOTA. INSTITUIÇÃO FINANCEIRA. SEGURADORA.

Agravo regimental em que se discute a aplicabilidade do art. 97 à declaração de inconstitucionalidade dos aumentos de alíquota do extinto Finsocial. Irrelevância, na medida em que o mérito do acórdão recorrido não seria revertido, por ter esta Corte definido que as instituições financeiras, como as seguradoras, não se submeteram à majoração do tributo. Agravo regimental ao qual se nega provimento.",30
\end{abstract}

\footnotetext{
27 CPC, art. 557: "O relator negará seguimento a recurso manifestamente inadmissível, improcedente, prejudicado ou em confronto com súmula ou com jurisprudência dominante do respectivo tribunal, do Supremo Tribunal Federal, ou de Tribunal Superior."

${ }^{28} \mathrm{CPC}$, art. 557, § $1^{\circ}$-A: "Se a decisão recorrida estiver em manifesto confronto com súmula ou com jurisprudência dominante do Supremo Tribunal Federal, ou de Tribunal Superior, o relator poderá dar provimento ao recurso."

29 Também confirma a assertiva os comentários de Gilmar Mendes ao discorrer sobre a transcendência dos fundamentos determinantes no controle difuso-incidental: “...são numericamente expressivos os casos em que o Supremo Tribunal tem estendido, com base no art. 557, caput, e $\S 1^{\circ}-\mathrm{A}$, do Código de Processo Civil, a decisão do plenário que declara a inconstitucionalidade de norma municipal a outras situações idênticas, oriundas de Municípios diversos.” Cf. MENDES, Gilmar Ferreira. Curso de Direito Constitucional. Op. cit. p, 1137

${ }^{30}$ STF, DJE, 28 maio 2010, RE 346.416 AgR/RJ, rel. Min. Joaquim Barbosa
} 
Vê-se que, já aí, introduziu-se, no ordenamento jurídico, um mecanismo apto a conferir efeitos, para além do caso concreto, a decisões incidentais do Pleno do STF acerca da constitucionalidade de uma norma.

\subsubsection{Dispensa de reexame necessário}

A Lei 10.352/2001 acresceu o $\S^{\circ}$ ao art. 475, CPC. ${ }^{31}$ Esse dispositivo regula a regra do reexame necessário de sentenças contrárias à Fazenda Pública, independentemente de apelação. Contudo, o referido parágrafo dispensa o reexame quando a decisão de primeiro grau de jurisdição estiver em consonância com a jurisprudência do plenário do STF. Ou seja: havendo decisão da Corte, em controle difuso-incidental, acerca da constitucionalidade de uma norma, e tendo o juiz de primeira instância decidido no mesmo sentido, pode nisso fundamentar a dispensa do reexame em favor da Fazenda.

Assim, uma vez mais, decisão do STF que teria efeitos restritos às partes acaba se estendendo, por disposição legal, a outros casos.

Isso é especialmente significativo quando se tem em conta que processos contra a Fazenda Pública possuem especial vocação para se multiplicar, gerando uma sucessão de causas idênticas. Logo, o impacto de dispositivo dessa natureza assume ainda mais relevância.

\subsubsection{Súmula impeditiva de recursos}

Outro instrumento que se pode dizer pretensamente generalizante dos efeitos das decisões da Suprema Corte, em controle difuso-incidental, é

31 CPC, art. 475: "Está sujeita ao duplo grau de jurisdição, não produzindo efeito senão depois de confirmada pelo tribunal, a sentença: I - proferida contra a União, o Estado, o Distrito Federal, o Município, e as respectivas autarquias e fundações de direito público; II - que julgar procedentes, no todo ou em parte, os embargos à execução de dívida ativa da Fazenda Pública (art. 585, VI); $\S 3^{\circ}$. Também não se aplica o disposto neste artigo quando a sentença estiver fundada em jurisprudência do plenário do Supremo Tribunal Federal ou em súmula deste Tribunal ou do tribunal superior competente." 
a súmula impeditiva de recursos, introduzida no art. $518, \S 1^{\circ}, \mathrm{CPC}^{32}$, pela Lei 11.276/2006.

A aludida disposição legal prevê que o juiz não receberá o recurso de apelação quando a sentença estiver em conformidade com súmula do STF. Em consequência, tratando a súmula de decisões da Corte em incidentes de inconstitucionalidade, a aplicação do dispositivo processual proporciona a generalização dos efeitos de tais julgados.

A Lei 11.276/2006, assim como todos os diplomas normativos que introduziram inovações semelhantes, foi alvo de críticas. Questionou-se a constitucionalidade da nova regra e se, de fato, promoveria a celeridade e a economia processuais, principais valores otimizados no discurso de seus defensores.

A par das controvérsias, o que aparentemente se constata é a pouca aplicabilidade da norma na prática dos tribunais. São poucos os casos em que os juízes inadmitem a apelação com fulcro no art. $518, \S 1^{\circ}, \mathrm{CPC}$. Isto se dá, sobretudo, porque a parte prejudicada sempre poderá interpor agravo dessa decisão (o que torna ainda mais moroso o desenvolvimento do processo) e porque a decisão deve ter como único fundamento determinante a súmula. ${ }^{33}$

\footnotetext{
${ }^{32} \mathrm{CPC}$, art. $518, \S 1^{\circ}$ : "O juiz não receberá o recurso de apelação quando a sentença estiver em conformidade com súmula do Superior Tribunal de Justiça ou do Supremo Tribunal Federal."

${ }^{33}$ Já prevendo essa consequência quando da edição da Lei 11.276/2006, Hugo de Brito Machado questionou a eficácia do novo dispositivo, comparando-o com o art. 557, CPC: “(...) fiz, como relator de processos no Tribunal Regional da 5a Região, cerca de dez despachos negando seguimento a recursos, e em todos os casos houve a interposição de agravos. Tive o trabalho de fazer os despachos e depois fazer os relatórios e votos, para submeter as questões ao colegiado. Vi que a novidade legislativa em nada contribuiu para diminuir o trabalho no Tribunal. Pelo contrário, o aumentou. Por isso não mais utilizei a faculdade que o novo dispositivo legal me atribuiu. Era muito mais fácil relatar o caso e levá-lo a julgamento. Minha experiência, portanto, autoriza-me a pensar que a inovação agora introduzida (tratando do art. 518, § 1o do CPC) também não vai produzir o efeito desejado". MACHADO, Hugo de Brito. Ampliação do juízo de admissibilidade na apelação - Lei. 11.276. Revista Dialética de Direito Processual n. 38. São Paulo: Dialética, 2006, p. 62-63.
} 


\subsubsection{Repercussão geral}

É de conhecimento geral que o recurso extraordinário se apresenta como o principal meio de exercício do controle difuso-incidental pelo STF. Através dele, é submetida à Suprema Corte a apreciação das arguições de inconstitucionalidade julgadas pelas instâncias ordinárias e incorporadas à decisão recorrida.

Além dos diversos requisitos de admissibilidade que já obstaculizavam a interposição desse recurso, a EC n. 45/2004 acrescentou mais um, no $\$ 3^{\circ}$ do art. 102 da $\mathrm{CRFB}^{34}$ : a repercussão geral.

Regulamentado pelo art. 543-A, $\mathrm{CPC}^{35}$ (acrescido pela Lei 11.418/2006), o novo instituto passou a exigir que a matéria ventilada no recurso extraordinário apresente relevância do ponto de vista econômico, político, social ou jurídico e que transcenda os interesses subjetivos das partes. Portanto, a resolução da questão constitucional que se pretenda discutir deve tocar não só a autor e réu, mas também a terceiros.

\footnotetext{
${ }^{34}$ CRFB, art. 102, $\S 3^{\text {o: }}$ : No recurso extraordinário o recorrente deverá demonstrar a repercussão geral das questões constitucionais discutidas no caso, nos termos da lei, a fim de que o Tribunal examine a admissão do recurso, somente podendo recusá-lo pela manifestação de dois terços de seus membros."

${ }^{35}$ CPC, art. 543-A: "O Supremo Tribunal Federal, em decisão irrecorrível, não conhecerá do recurso extraordinário, quando a questão constitucional nele versada não oferecer repercussão geral, nos termos deste artigo.

$\S 1^{\circ}$. Para efeito da repercussão geral, será considerada a existência, ou não, de questões relevantes do ponto de vista econômico, político, social ou jurídico, que ultrapassem os interesses subjetivos da causa.

$\S 2^{\circ}$. O recorrente deverá demonstrar, em preliminar do recurso, para apreciação exclusiva do Supremo Tribunal Federal, a existência da repercussão geral.

$\S 3^{\circ}$. Haverá repercussão geral sempre que o recurso impugnar decisão contrária a súmula ou jurisprudência dominante do Tribunal.

$\S 4^{\circ}$. Se a Turma decidir pela existência da repercussão geral por, no mínimo, 4 (quatro) votos, ficará dispensada a remessa do recurso ao Plenário.

$\S 5^{\circ}$. Negada a existência da repercussão geral, a decisão valerá para todos os recursos sobre matéria idêntica, que serão indeferidos liminarmente, salvo revisão da tese, tudo nos termos do Regimento Interno do Supremo Tribunal Federal.

$\S 6^{\circ}$. O Relator poderá admitir, na análise da repercussão geral, a manifestação de terceiros, subscrita por procurador habilitado, nos termos do Regimento Interno do Supremo Tribunal Federal.

$\S 7^{\circ}$. A Súmula da decisão sobre a repercussão geral constará de ata, que será publicada no Diário Oficial e valerá como acórdão."
} 
Diante dessa evidente feição objetiva conferida pela repercussão geral ao recurso extraordinário, a decisão que negue a sua existência valerá para todos os recursos sobre matéria idêntica, que serão automaticamente inadmitidos. Assim dispõe o $\$ 5^{\circ}$ do art. 543-A, CPC:

"§ $5^{\circ}$. Negada a existência da repercussão geral, a decisão valerá para todos os recursos sobre matéria idêntica, que serão indeferidos liminarmente, salvo revisão da tese, tudo nos termos do Regimento Interno do Supremo Tribunal Federal."

É justamente nessa regra que reside a relevância do instituto para a teoria da abstrativização do controle difuso-incidental. ${ }^{36}$ Isto porque, a decisão relativa a um caso concreto específico acaba tendo seus efeitos estendidos a outros processos, aproximando-a de uma decisão proferida em ação direta.

Somada a isso, a possibilidade - prevista no $§ 6^{\circ}$ do art. 543-A, CPC - de que o relator do recurso extraordinário admita a participação de terceiros, na análise da repercussão geral, parece confirmar o intuito generalizante do instituto. ${ }^{37}$ Com efeito, inserir o amicus curiae - figura típica dos processos objetivos - na aferição desse requisito foi um modo

\footnotetext{
${ }^{36}$ Eduardo Francisco de Souza, ao escrever artigo sobre o tema, assim anotou: "A relevância do instituto para a tendência de objetivação observada está em que o decidido pelo STF, quando da análise deste novo requisito de admissibilidade, vinculará os futuros casos semelhantes que futuramente sejam submetidos a julgamentos. Emprestando interpretação ao tema, Teresa Arruda Alvim Wambier, Luiz Rodrigues Wambier e Garcia Medina pontificam: 'Pensamos, assim, que havendo jurisprudência firme do pleno no sentido de que dada questão não tem repercussão geral, recursos extraordinários futuros que veiculem questões jurídicas idênticas poderão ser rejeitados por uma das turma do STF ou até pelo próprio relator do recurso (cf. art. 557 do CPC) e não necessariamente por dois terços do pleno'." Cf. SOUZA, Eduardo Francisco de. A abstração do controle difuso de constitucionalidade. Revista Jurídica, Brasília, v. 9, n. 89, p.01-23, fev./mar, 2008. Disponível em <http://www.presidencia.gov.br/revistajuridica〉. Acesso em 15 de julho de 2012.

${ }^{37}$ Veja-se a colocação de Pedro Rafael Malveira Deocleciano e José Péricles Pereira de Sousa: "Esse sentimento de objetivação foi ainda mais acentuado pela possibilidade da participação de terceiros, quando da análise da repercussão geral, em sede de recurso extraordinário. Situação acrescentada pela Lei 11.418/06, inserindo nova disposição ao Código de Processo Civil (art. 543A, $\S 6^{\circ}$ ). Assim, no ímpeto de atestar a relevância da matéria a ser apreciada pelo STF, em decorrência da comprovação dos requisitos estabelecidos na lei da repercussão geral, a participação do amicus curiae realça o caráter abstrato de uma discussão inicialmente subjetiva, enfatizando, assim, objetivamente, a questão constitucional observada, semelhante a outros casos concretos." Cf. DEOCLECIANO, Pedro Rafael Malveira; SOUSA, José Péricles Pereira. A objetivação do controle difuso na ordem jurídica brasileira. Revista Direitos Fundamentais \& Democracia, UniBrasil - Faculdades Integradas do Brasil, v. 6, 2009. Disponível em <http://www.revistaeletronicardfd.unibrasil.com.br>. Acesso em 15 de julho de 2012.
} 
encontrado pelo legislador de legitimar a extensão dos efeitos da decisão para além do caso concreto.

Conforme leciona Luís Roberto Barroso, o objetivo dessa extensão de efeitos da decisão relativa à repercussão geral teria sido "otimizar o trabalho da Corte, evitando a multiplicação de julgamentos idênticos". 38

\subsubsection{Sistemática de julgamento de recursos repetitivos}

Também no intuito de evitar o acúmulo de demandas repetidas a serem julgadas pelo STF, a Lei 11.418/2006 previu um regramento especial para o julgamento de recursos relativos a uma mesma questão jurídica. Esse regramento foi incorporado ao diploma processual civil no art. 543-B e parágrafos. $^{39}$

Em síntese, o Presidente do Tribunal recorrido seleciona um ou mais recursos para representar a controvérsia. Enquanto os selecionados são analisados pela Suprema Corte, os demais ficam sobrestados na origem.

Consoante já assinalado, negada a repercussão geral pelo STF, essa decisão é válida para os demais recursos sobre a mesma matéria. Assim, na sistemática dos recursos repetitivos, não havendo repercussão geral reconhecida aos recursos selecionados, os recursos sobrestados são automaticamente inadmitidos.

\footnotetext{
${ }^{38}$ Cf. BARROSO, Luís Roberto. Op. cit., p. 143.

${ }^{39} \mathrm{CPC}$, art. 543-B. "Quando houver multiplicidade de recursos com fundamento em idêntica controvérsia, a análise da repercussão geral será processada nos termos do Regimento Interno do Supremo Tribunal Federal, observado o disposto neste artigo.

$\S 1^{\circ}$. Caberá ao Tribunal de origem selecionar um ou mais recursos representativos da controvérsia e encaminhá-los ao Supremo Tribunal Federal, sobrestando os demais até o pronunciamento definitivo da Corte.

$\S 2^{\circ}$. Negada a existência de repercussão geral, os recursos sobrestados considerar-se-ão automaticamente não admitidos.

$\S 3^{\circ}$. Julgado o mérito do recurso extraordinário, os recursos sobrestados serão apreciados pelos Tribunais, Turmas de Uniformização ou Turmas Recursais, que poderão declará-los prejudicados ou retratar-se.

$\S 4^{\circ}$. Mantida a decisão e admitido o recurso, poderá o Supremo Tribunal Federal, nos termos do Regimento Interno, cassar ou reformar, liminarmente, o acórdão contrário à orientação firmada. $\S 5^{\circ}$. O Regimento Interno do Supremo Tribunal Federal disporá sobre as atribuições dos Ministros, das Turmas e de outros órgãos, na análise da repercussão geral."
} 
Por outro lado, reconhecida a repercussão geral nos recursos paradigmas, é julgado o seu mérito. Em seguida, os recursos sobrestados serão apreciados pelos Tribunais, Turmas de Uniformização ou Turmas Recursais, que poderão declará-los prejudicados ou retratar-se, de acordo com o teor da decisão proferida pelo STF. Não o fazendo, poderá a Corte cassar ou reformar, liminarmente, o acórdão contrário à decisão firmada.

É de se ver, deste modo, que a sistemática inaugurada aproximou ainda mais os dois modelos de controle presentes no ordenamento jurídico brasileiro.

A esse propósito, trazem-se as lições de Eduardo Appio ao comentar a inovação inserida pelo art. 543-B, CPC, in verbis:

\begin{abstract}
"O tempo do controle difuso era o passado, e o inverso sucedia com o controle concentrado, voltado quase que exclusivamente para as situações futuras. [...] Este cenário mudou radicalmente desde fevereiro de 2008, quando então o Supremo Tribunal Federal passou a considerar que as decisões proferidas em sede de controle difuso (concreto), que até então atingiam apenas as partes (inter partes), também poderiam - a exemplo do controle concentrado - atingir terceiros. Passaram-se, então, quase quarenta anos, desde a adoção do sistema concentrado no Brasil, para que o Supremo Tribunal Federal pudesse dar os primeiros passos de aproximação entre os dois modelos.[...] Este foi o prenúncio histórico de que os dois modelos iniciariam um movimento de lenta (mas constante) aproximação, o qual culminou com o recente modelo implantado no STF, no qual se advoga a eficácia erga omnes e com efeitos retroativos, mesmo no controle difuso." ${ }^{40}$
\end{abstract}

Não obstante, aqui, a lei parece não ter estabelecido uma vinculação formal dos tribunais à decisão do Supremo, na medida em que o $\S 4^{\circ}$ do art. 543-B, CPC admite, ainda que implicitamente, a possibilidade de que o tribunal mantenha a sua decisão originária. ${ }^{41}$

É o que se extrai, igualmente, das lições de Luís Roberto Barroso, que prefere falar em uma vinculação lógica e não formal:

\footnotetext{
${ }^{40}$ APPIO, Eduardo apud MACEDO, Luana Vargas. Parecer PGFN/CRJ/N.492/2011. Revista da PGFN, Ano 1, Número 2. 2011. p. 214. Disponível em <http://www.pgfn.fazenda.gov.br>. Acesso em 21 de julho de 2012.

${ }^{41}$ Versa o referido dispositivo: "Mantida a decisão e admitido o recurso, poderá o Supremo Tribunal Federal, nos termos do Regimento Interno, cassar ou reformar, liminarmente, o acórdão contrário à orientação firmada".
} 
"Embora essa previsão (do art. 543-B, §4, $\mathrm{CPC}$ ) pareça sugerir a possibilidade de atuação imediata da Corte, a jurisprudência caminhou no sentido de afirmar que a reforma ou cassação da decisão incompatível com o precedente deverá ocorrer em sede de eventual recurso extraordinário, não se justificando o uso da reclamação. De toda forma, a indicação do legislador é clara e aponta no sentido de uma desejável vinculação lógica dos juízos inferiores às decisões da Suprema Corte - vinculação fundada em um imperativo de racionalidade e isonomia, sem prejuízo de se admitirem exceções diante de motivos relevantes, devidamente demonstrados -, embora não seja possível dizer que tenha sido estabelecida uma vinculação jurídica formal " 42

Mas, em que pese a ausência de vinculação jurídica, é inegável que a previsão legislativa torna a adoção das decisões do STF a regra, sendo as decisões contrárias, exceções. Dota-as, melhor dizendo, de um elevado grau de estabilidade. ${ }^{43}$ Deste modo, vê-se que os dispositivos supracitados cumprem um papel generalizante dos efeitos de decisões do Supremo Tribunal proferidas em controle difuso-incidental.

\subsection{Supressão do princípio da reserva de plenário}

Alteração legislativa que merece estudo em $\operatorname{apartado}^{44}$ é aquela que introduziu, ainda no ano de 1998, o parágrafo único ao art. 481, CPC. Esse dispositivo regula a cláusula da reserva de plenário (art. 97, CRFB).

Conforme anteriormente exposto, em linhas gerais, a reserva de plenário foi instituída na Constituição de 1934 e perdura até hoje. Quer dizer que, para um tribunal infirmar a constitucionalidade de uma norma, deve obter o voto de, pelo menos, a maioria absoluta de seus membros. A regra constitucional se assenta no princípio da presunção de constitucionalidade das leis. ${ }^{45}$ Tanto a declaração de inconstitucionalidade

\footnotetext{
${ }^{42}$ BARROSO, Luís Roberto. Op. cit., p. 146.

${ }^{43}$ Essa é a expressão utilizada pela Procuradora da Fazenda Nacional, Luana Vargas Macedo em MACEDO, Luana Vargas. Op. cit. 217

${ }^{44}$ Assim foi considerado tendo em vista ter se tratado de alteração empreendida diretamente sobre o modo de julgamento, constitucionalmente previsto, do incidente de inconstitucionalidade.

${ }^{45}$ Nos dizeres de Marcelo Caetano, citado pelo Ministro Celso de Mello (RE 190.725-8/PR): “...a exigência de maioria qualificada para a declaração da inconstitucionalidade de lei ou ato normativo justifica-se pela preocupação de só permitir ao Poder Judiciário tal declaração quando o vício seja manifesto e, portanto, salte aos olhos de um grande número de julgadores experientes caso o órgão seja colegiado. Sendo atingida a majestade da lei a qual, em princípio, se beneficia da presunção de estar de acordo com a Constituição, é necessário que o julgamento resulte de um
} 
em controle difuso-incidental como em controle concentrado-principal está sujeita à reserva de plenário.

$\mathrm{Na}$ via incidental, arguida a inconstitucionalidade, o relator submeterá a questão à turma ou a câmara (órgãos fracionários). Esta decidirá pela sua rejeição ou acolhimento. Rejeitada a arguição, o julgamento prosseguirá. Por outro lado, caso acolhida, deverá o órgão fracionário submetê-la ao plenário do tribunal para que este decida o incidente. ${ }^{46}$ Em apertada síntese, é este o procedimento previsto pelos arts. 480 a 482, CPC.

Não há dúvidas de que a decisão do Pleno vincula o órgão fracionário no julgamento do caso concreto originário do incidente. Tomar como premissa conclusão diversa seria violar a cláusula da reserva de plenário, a qual está protegia, inclusive, por súmula vinculante. ${ }^{47}$

No entanto, começaram a surgir vozes, na jurisprudência, no sentido de que a existência de decisão do Pleno do STF (ou do próprio Tribunal) acerca da constitucionalidade de determinada norma, dispensaria os órgãos fracionários da observância da reserva de plenário no julgamento de outros casos envolvendo a mesma disposição normativa. Ou seja, pretendeu-se conferir efeitos generalizantes a decisões tomadas pela Suprema Corte em controle difuso-incidental. ${ }^{48}$

\footnotetext{
consenso apreciável e não brote de qualquer escassa maioria (...). Essa exigência, por outro lado, acautela contra uma futura variação de jurisprudência no mesmo Tribunal. Assim, a inconstitucionalidade tem de ser declarada pelos votos conformes de um número de juízes equivalente a metade mais um dos membros do Tribunal ou do órgão competente nele formado". Retirado de LENZA, Pedro. Op. cit., p. 180

${ }^{46}$ No controle incidental exercido no âmbito dos tribunais, há cisão entre o julgamento do incidente e o julgamento da causa. O processo fica suspenso aguardando a decisão plenária acerca do incidente. Uma vez proferida, a decisão é remetida ao órgão fracionário que prosseguirá no julgamento do feito, tendo como premissa lógica a decisão do pleno. Diferentemente, instaurado o incidente no âmbito do STF, após julgá-lo, o plenário prossegue no julgamento da causa.

${ }^{47}$ STF, Súmula Vinculante n. 10: "Viola a cláusula de reserva de plenário (CF, artigo 97) a decisão de órgão fracionário de tribunal que, embora não declare expressamente a inconstitucionalidade de lei ou ato normativo do poder público, afasta sua incidência, no todo ou em parte".

${ }^{48}$ Havendo decisão do STF proferida em sede de controle concentrado-principal, os seus efeitos já são automaticamente erga omnes e vinculantes, de modo que os tribunais precisam seguir a orientação firmada. Nesse caso, não há sequer que se falar em submissão ou não da questão ao plenário.
} 
Conforme manifestou-se o Min. Marco Aurélio, essa conclusão partiria de uma interpretação teleológica do art. 97, CRFB. O dispositivo visaria evitar a apreciação da inconstitucionalidade pelos órgãos fracionários apenas quando fosse nova a questão arguida. Já existindo manifestação do STF, guardião máximo da Constituição, tornar-se-ia dispensável a observância da cláusula, em homenagem aos princípios da economia e da celeridade. $^{49}$

A Lei 9.756/98 pareceu confirmar a tendência que se observava jurisprudencialmente. Referido diploma normativo introduziu o parágrafo único ao art. 481, CPC, conferindo-lhe a seguinte redação:

“Art. 481. Parágrafo Único. Os órgãos fracionários dos tribunais não submeterão ao plenário, ou ao órgão especial, a arguição de inconstitucionalidade, quando já houver pronunciamento destes ou do plenário do Supremo Tribunal Federal sobre a questão”.

Com efeito, independentemente da leitura que se faça do dispositivo, é certo que ele representou um mecanismo a conferir força aos precedentes do STF em controle difuso-incidental. Possibilitou, ao menos de modo mais contundente, que os efeitos de decisão incidental da Corte se expandam para além do caso concreto.

A dúvida que se pode encontrar na doutrina e que possui pertinência ao tema da abstrativização é se a decisão do plenário do Supremo efetivamente vincularia, ou não, os órgãos fracionários dos tribunais, sob pena de invalidade ou reforma da decisão por eles emanada. Tradicionalmente, no modelo em que concebido o controle de constitucionalidade brasileiro, não deveria haver vinculação, pois, em

\footnotetext{
49 STF, $2^{\text {a }}$ T., Ag. 168.149, rel. Min. Marco Aurélio, RTJ 162/765: "EMENTA: Inconstitucionalidade - Incidente - Deslocamento do processo para o Órgão Especial ou para o Pleno - Desnecessidade. Versando a controvérsia sobre ato normativo já declarado inconstitucional pelo guardião maior da Carta Política - o Supremo Tribunal Federal - descabe o deslocamento previsto no art. 97 do referido Diploma maior. O julgamento de plano pelo órgão fracionado homenageia não só a racionalidade, como também a interpretação teleológica do artigo 97 em comento, evitando a burocratização dos atos judiciais no que nefasta ao princípio da economia e da celeridade. A razão de ser do preceito está na necessidade de evitar-se que órgãos fracionados apreciem, pela vez primeira, a pecha de inconstitucionalidade arguida em relação a um certo ato normativo."
} 
controle incidental, a decisão do STF é obrigatória apenas para as partes. Assim, o dispositivo deveria indicar tão somente uma recomendação aos demais órgãos julgadores diante de casos semelhantes.

Mas, para grande parte da doutrina, o dispositivo teria, sim, caráter vinculante. Nagib Slaibi Filho, ao escrever sobre o tema, assim posicionouse:

\begin{abstract}
"Vê-se, assim, que mui discretamente, o parágrafo único do art. 481 do Código de Processo Civil cristalizou normativamente o que a doutrina e a jurisprudência admitiam: a vinculação dos tribunais às decisões do Supremo Tribunal Federal no reconhecimento incidental da inconstitucionalidade, mesmo porque bastava, e ainda basta, ao relator, para não se conhecer de recurso constitucional, o fundamento de que o tema já fora apreciado pelo Excelso Pretório."
\end{abstract}

E o autor foi além, refutando o argumento de que, interpretado deste modo, o dispositivo seria inconstitucional. Sugeriu, isto sim, o cabimento de reclamação contra a decisão do órgão fracionário que não observe a decisão do STF. Veja-se:

\begin{abstract}
"Nem se pode arguir de inconstitucional a nova disposição ora em comento, sob o argumento de restringir a autonomia dos tribunais ou dos seus órgãos ou integrantes. O art. 99 da Constituição garante é a autonomia do Poder Judiciário e não dos tribunais - e não pode agitar malferimento da autonomia funcional dos juízes aqueles que estão jungidos ao reconhecimento da inconstitucionalidade pelo Plenário ou órgão especial do próprio Tribunal e, no tema constitucional, a Constituição erigiu a Suprema Corte ao papel de seu guardião. Aliás, se o Tribunal, por seu órgão fracionário ou mesmo pelo Pleno, ignorar a norma proibitiva contida no dispositivo em comento, estará desafiando, de um lado, recurso no Superior Tribunal de Justiça por vulneração da norma decorrente do dispositivo no mencionado parágrafo único do art. 481, e, de outro, a reclamação prevista no art. 102, I, 'l', da Constituição, a garantir a competência e a autoridade do mais Alto Tribunal do país."
\end{abstract}

No mesmo sentido, expressou-se Gilmar Mendes, para quem a decisão do Supremo Tribunal Federal, tal como colocada, antecipa o efeito vinculante dos seus julgados em matéria de controle incidental. ${ }^{52}$

\footnotetext{
${ }^{50}$ FILHO, Nagib Slaibi. A arguição de inconstitucionalidade nos tribunais: notas sobre a nova redação que a Lei n. 9.756/98 deu ao art. 481 do CPC. Revista Jus Navigandi. Disponível em <http://www.jus.com.br>. Acesso em 12 de julho de 2012.

${ }^{51}$ Ibid.

${ }^{52}$ MENDES, Gilmar Ferreira et al. Curso de Direito Constitucional. Op.cit. p. 1133
} 
Essa também a posição de Teori Albino Zavascki, que afirma, ademais, prevalecer o pronunciamento do STF sobre o do plenário do tribunal, caso sejam conflitantes:

\begin{abstract}
"Pode ocorrer que, antes do pronunciamento do Supremo haja decisão do Pleno ou do órgão especial do tribunal local em sentido contrário. A qual deles estará vinculado o órgão fracionário? Inquestionavelmente ao Supremo, e isso é conclusão que decorre não só da supremacia que ostenta, em face de todos os outros, o Tribunal guardião da Constituição, como dos próprios princípios constitucionais acima referidos, que ensejam a dispensa do incidente. A se admitir a orientação contrária, restariam comprometidos os princípios da economia, da celeridade, da racionalidade dos serviços judiciários, da segurança e da igualdade. ${ }^{.53}$
\end{abstract}

Observe-se que nenhum desses autores faz diferença quanto à vinculação conforme o teor do pronunciamento do STF. Para todos, seja a decisão pela constitucionalidade ou pela inconstitucionalidade, deve o órgão fracionário adotá-la no julgamento de casos que envolvam a mesma norma.

Ostentando posicionamento contrário, em interessante artigo sobre o tema, Fábio Carvalho Leite defende que o parágrafo único do art. 481, CPC prevê mera liberalidade do órgão fracionário. $\mathrm{O}$ dispositivo apenas autorizaria a dispensa de submissão da questão ao plenário caso o órgão fracionário entenda pela inconstitucionalidade de norma assim já declarada pelo STF em outro caso concreto. O autor parece negar que a intenção do preceito normativo seja a de conferir efeitos vinculantes à decisão em controle difuso-incidental. Leia-se trecho elucidativo sobre sua posição:

"Esta compreensão, mais ampla, abarcando qualquer entendimento do STF sobre
a questão, seja pela constitucionalidade, seja pela inconstitucionalidade,
certamente satisfaria os desejos das correntes que associam o dever de guarda da
Constituição, conferido ao STF, a praticamente um monopólio na interpretação
da Lei Fundamental. Mas, para além das críticas que podem ser dirigidas a esta
premissa, deve-se também recordar que as declarações de constitucionalidade em
sede de controle concreto-difuso, mesmo quando proferidas pelo STF, não
possuem efeito vinculante (...).
Assim, parece que a melhor interpretação do dispositivo processual seria a de que
o órgão fracionário, como decorrência do princípio da presunção de

${ }^{53}$ ZAVASCKI, Teori Albino. Op. cit. p. 36 
constitucionalidade dos atos normativos, estará sempre autorizado a aplicar uma lei, mesmo que haja decisão do STF ou do tribunal pleno, em sede de controle concreto-difuso, pela inconstitucionalidade da norma (...).

Por outro lado, caso o órgão fracionário entenda que a lei é inconstitucional, deve-se assumir que, a princípio, estará obrigado a encaminhar a questão ao pleno - dever somente afastado se já houver decisão do STF ou do próprio pleno no mesmo sentido. Não se trata, como visto, de vinculação ao que fora decidido pelo STF ou pelo pleno. Simplesmente, neste caso, a existência de uma declaração de inconstitucionalidade afastaria a presunção de constitucionalidade da lei e, pelo disposto no CPC, autorizaria o órgão fracionário a não submeter a questão ao pleno." ${ }^{, 5}$

Por fim, cabe salientar que há também quem defenda posição intermediária.

Em obra que decorreu de sua dissertação de doutorado, Patrícia Perrone classifica a eficácia dos precedentes judiciais brasileiros em três categorias: (i) precedentes com eficácia normativa, que estabelecem entendimentos de observância obrigatória, (ii) precedentes com eficácia impositiva intermediária, que não têm obrigatoriedade de ser seguidos, mas que possuem efeitos impositivos (ainda que mais brandos) para além do caso examinado e (iii) precedentes com eficácia meramente persuasiva, que apenas são invocados para fins de argumentação. ${ }^{55}$

É nessa linha que, após discorrer sobre a dispensa da reserva de plenário, a autora atenta para a evolução pela qual passa o sistema difusoincidental. Não obstante, assevera que a evolução tem consistido, até agora, em se conferir eficácia impositiva e para além do caso julgado às decisões proferidas nessa sede. ${ }^{56}$ Vale dizer: não haveria vinculação jurídica formal do órgão fracionário à decisão do STF, sob pena de invalidade ou reforma, mas a sua não auto aplicação implicaria árduo ônus argumentativo aos julgadores, além de severas críticas, as quais, provavelmente, levariam à revisão da decisão.

\footnotetext{
${ }^{54}$ LEITE, Fábio Carvalho. A cláusula da reserva de plenário segundo os Tribunais de Justiça. Custos Legis. Revista eletrônica do Ministério Público Federal. Disponível em $<$ http://www.prrj.mpf.gov.br>. Acesso em 12 de julho de 2012.

${ }^{55}$ MELLO, Patrícia Perrone Campos. Precedentes - O desenvolvimento judicial do direito no constitucionalismo contemporâneo. Rio de Janeiro: Renovar, 2008, p. 62-66

${ }^{56}$ Ibid. p. 84
} 
Mencione-se, contudo, que a própria autora, mais a frente, reconhece que, diante do processo de aproximação do sistema difuso ao sistema concentrado, as decisões do pleno do STF, atualmente, podem ser qualificadas como de eficácia impositiva intermediária a caminho da eficácia normativa. ${ }^{57}$

\subsection{Súmula vinculante}

Para muitos, dentre todos os mecanismos positivados de aproximação do controle difuso-incidental ao controle concentradoprincipal, talvez a súmula vinculante seja aquele que melhor legitime essa tendência.

Introduzida pela EC n. 45/2004, sua previsão consta do art. 103-A, CRFB, assim redigido:

\footnotetext{
“Art. 103-A. O Supremo Tribunal Federal poderá, de ofício ou por provocação, mediante decisão de dois terços dos seus membros, após reiteradas decisões sobre matéria constitucional, aprovar súmula que, a partir de sua publicação na imprensa oficial, terá efeito vinculante em relação aos demais órgãos do Poder Judiciário e à administração pública direta e indireta, nas esferas federal, estadual e municipal, bem como proceder à sua revisão ou cancelamento, na forma estabelecida em lei.
}

$\S 1^{\circ}$ A súmula terá por objetivo a validade, a interpretação e a eficácia de normas determinadas, acerca das quais haja controvérsia atual entre órgãos judiciários ou entre esses e a administração pública que acarrete grave insegurança jurídica e relevante multiplicação de processos sobre questão idêntica.

$\S 2^{\circ}$ Sem prejuízo do que vier a ser estabelecido em lei, a aprovação, revisão ou cancelamento de súmula poderá ser provocada por aqueles que podem propor a ação direta de inconstitucionalidade.

$\S 3^{\circ}$ Do ato administrativo ou decisão judicial que contrariar a súmula aplicável ou que indevidamente a aplicar, caberá reclamação ao Supremo Tribunal Federal que, julgando-a procedente, anulará o ato administrativo ou cassará a decisão judicial reclamada, e determinará que outra seja proferida com ou sem a aplicação da súmula, conforme o caso."

\footnotetext{
${ }^{57}$ Ibid. p. 108
} 
A súmula vinculante é instrumento pelo qual a Suprema Corte sintetiza uma doutrina adotada em diversos julgados semelhantes, conferindo-lhe eficácia normativa. ${ }^{58}$

Diferentemente dos institutos até então introduzidos, em que não se poderia afirmar, com convicção, uma vinculação jurídica formal dos demais órgãos do Poder Judiciário à orientação firmada pelo STF, na súmula vinculante, tal efeito foi previsto de forma expressa. Disso não deixou dúvidas o regramento constitucional, sobretudo, ao autorizar o uso de reclamação contra atos do Poder Judiciário ou da Administração Pública que contrariem o conteúdo veiculado no verbete. ${ }^{59}$ Em consequência, poderse-ia falar, até mesmo, em responsabilidade funcional da autoridade pública emissora do ato, caso verificado reiterado descumprimento de verbete sumular. ${ }^{60}$

É nesse sentido que parte da doutrina afirma que a súmula vinculante foi a positivação que melhor representou a aproximação dos efeitos das decisões em controle difuso-incidental daqueles produzidos pelos julgados do controle concentrado-principal.

Nesse contexto, acentuou André Ramos Tavares:

"Com a criação da súmula vinculante, construiu-se uma ponte definitiva entre o controle difuso-concreto da constitucionalidade das leis e o controle abstratoconcentrado, já que as decisões proferidas no primeiro contexto poderão alcançar os efeitos próprios do segundo modelo, desde que sejam incorporadas no enunciado de uma súmula vinculante."

\footnotetext{
${ }^{58}$ Definição retirada de MELLO, Patrícia Perrone Campos. Op. cit., p. 102

${ }^{59}$ Ao comentar os efeitos vinculantes conferidos ao instituto, Luís Roberto Barroso observa: "Em qualquer caso, a vinculação de que se trata não equivale a um dever de aplicação automática das súmulas. A realidade pode apresentar inúmeras variáveis, e cabe ao aplicador verificar se a situação concreta submetida a julgamento enquadra-se efetivamente na situação-tipo que a súmula pretendeu capturar. Ainda quando se verifique a correspondência, é possível que circunstâncias excepcionais façam com que a súmula não deve ser aplicada, a fim de evitar a produção de um resultado incompatível com a Constituição.” Cf. BARROSO, Luís Roberto. Op. cit., p. 109-110.

${ }^{60}$ Nesse sentido, André Ramos Tavares em TAVARES, André Ramos. Perplexidades do Novo Instituto da Súmula Vinculante no Direito Brasileiro. Revista Eletrônica de Direito do Estado (REDE), Salvador, Instituto Brasileiro de Direito Público, no. 11, julho/agosto/setembro, 2007. Disponível em <http://www.direitodoestado.com>. Acesso em 13 de julho de 2012.

${ }^{61}$ TAVARES, André Ramos. Curso de Direito Constitucional. $7^{\mathrm{a}}$ ed. São Paulo: Saraiva, 2009. p. 284
} 
De fato, a eficácia erga omnes e a vinculação, formalmente prevista, pareceram confirmar a tendência que já se notava na jurisprudência: conferir-se efeitos generalizantes e impositivos aos precedentes do STF em controle difuso-incidental, ainda que sem equiparar os dois modelos de controle, por não serem automáticos tais efeitos.

Tal teria se dado, assim como nos demais mecanismos apontados, por motivos de racionalização da jurisdição, de isonomia e de segurança jurídica. É o que se extrai das lições de Luís Roberto Barroso:

"Em uma realidade de litígios de massa, não é possível o apego às formas tradicionais de prestação artesanal de jurisdição. A súmula vinculante permite a enunciação objetiva da tese jurídica a ser aplicada a todas as hipóteses que envolvam questão idêntica. Como consequência, contribui para a celeridade e eficiência na administração da justiça, bem como para a redução do volume de recursos que chega ao STF." 62

Mais a frente, prossegue o insigne doutrinador:

“...a súmula apenas confere eficácia geral a uma linha de decisão estabelecida na Corte, que presumivelmente seria reproduzida em todo e qualquer caso similar que chegasse ao STF. O que a súmula faz é tentar produzir, já nas instâncias ordinárias, a observância desse entendimento, promovendo valores como isonomia e eficiência na prestação jurisdicional." ${ }^{\text {, } 33}$

É certo que, especialmente no que se refere aos efeitos vinculantes, o instituto teve a sua constitucionalidade bastante questionada. Severas críticas giraram em torno, principalmente, do amplo poder conferido ao STF e das graves consequências que isso acarretaria. Foram apontadas, dentre outras, a usurpação da função legislativa e a ausência de legitimidade democrática $^{64}$, o cerceamento da independência funcional dos juízes ${ }^{65}$ e o engessamento do direito. ${ }^{66}$

\footnotetext{
${ }^{62}$ BARROSO, Luís Roberto. Op. cit., p. 103

${ }^{63}$ Ibid. p. 108

${ }^{64}$ Vejam-se as críticas de Lênio Luiz Streck: "Com o poder constitucional de vincular o efeito das Súmulas e até mesmo das decisões de mérito do Supremo Tribunal Federal, o Poder Judiciário, por suas cúpulas, passará a legislar, o que, à evidência, quebrará a harmonia e a independência que deve haver entre os Poderes da República. Daí é urgente que se indague acerca da legitimidade do Poder Judiciário para tal." Cf. STRECK, Lênio Luiz. O fahrenheit sumular do Brasil: o controle panóptico da justiça. Disponível em <http://www.leniostreck.com.br>. Acesso em 13 de julho de 2012.

${ }^{65}$ Em relação à violação à autonomia do magistrado, Luiz Flavio Gomes: “A inconstitucionalidade da súmula vinculante é evidente. Toda interpretação, dada por um Tribunal a uma lei ordinária, por
} 
A despeito das controvérsias (mais bem analisadas no Capítulo 4, que aborda as críticas à aproximação dos modelos de controle e à teoria da abstrativização), o fato é que o instituto se consolidou e, hoje, já temos o equivalente a trinta e dois enunciados aprovados.

Todavia, há que se ressaltar que a aproximação aos efeitos do modelo concentrado-principal, proporcionada pela súmula vinculante, não significou inovação, a tal ponto, de se conferir efeitos erga omnes e vinculantes automáticos a qualquer decisão da Suprema Corte em controle difuso-incidental. Apenas aquelas decisões que derem origem ao verbete passam a ter seus efeitos generalizados, com observância obrigatória.

Neste ponto, revela-se oportuno destacar que as súmulas vinculantes ostentam teses jurídicas e, portanto, razões de decidir dos julgados e não os seus dispositivos. Já se viu, inclusive, que a questão constitucional decidida em processos subjetivos integra somente a fundamentação da decisão.

Mas, ainda em relação às características que afastam o instituto da súmula vinculante de uma completa equiparação dos efeitos dos dois modelos de controle, imperioso atentar para o procedimento necessário à aprovação do verbete.

$\mathrm{O}$ art. 103-A, CRFB exige quórum de dois terços dos Ministros do Supremo para que o enunciado seja aprovado, ou seja, ao menos oito dos onze membros da Corte precisam ser favoráveis ao seu conteúdo. Além disso, é condição, para a edição da súmula, a existência de reiteradas decisões, em um mesmo sentido, acerca da matéria constitucional. Sobre ela, é preciso que se verifique controvérsia relevante entre órgãos

mais sábia que seja, jamais pode vincular os juízes das instâncias inferiores, que devem julgar com absoluta e total independência. A súmula vinculante viola a independência jurídica do juiz, isto é, sua independência interna (dentro da e frente à própria instituição a que pertence). Ninguém pode impor ao juiz qualquer orientação sobre qual deve ser a interpretação mais correta. Aliás, é muito comum que um texto legal, pela sua literalidade confusa, permita mais de uma interpretação. De todas, deve prevalecer a que mais se coaduna com os princípios constitucionais (sobretudo o da razoabilidade). Mas o juiz sempre tem a liberdade de escolha, dentre todas as interpretações possíveis." Cf. GOMES, Luiz Flávio. Súmula Vinculante. Disponível em <http://www.mundojuridico.adv.br>. Acesso em 13 de julho de 2012.

${ }^{66}$ Novamente, nas palavras de Lênio Luiz Streck: "Ao impingirem o pensamento único acerca do Direito, as súmulas impedem novas leituras, novas interpretações. É claro que, com a institucionalização da súmula vinculante, não se queimarão livros; o problema será a queima das ideias (divergentes)!” Cf. STRECK, Lênio Luiz. Op. cit. 
judiciários ou entre estes e a Administração Pública. A disciplina constitucional também estabelece que a aprovação do verbete, bem como a sua revisão e cancelamento, poderão ser provocados pelos legitimados à propositura da ação direta de inconstitucionalidade, sem prejuízo do que dispuser a lei. ${ }^{67}$

Mencione-se, ademais, a necessária audiência do Procurador Geral da República ${ }^{68}$ e a possibilidade da manifestação de amicus curiae $^{69}$, de modo a dar consistência ao debate travado previamente à aprovação do enunciado.

É de se recordar, da mesma forma, que a súmula vinculante, quando veicula entendimento do STF sobre a inconstitucionalidade de uma norma, não a extirpa do ordenamento jurídico. Ela continua vigente e válida. Torna-se, porém, praticamente inútil enquanto vigorar a orientação vinculante. Nada impede, contudo, que o STF venha a rever o seu posicionamento, cancelando ou revisando a súmula. Isto ocorrendo, a norma, inutilizável sob o império sumular, readquire, novamente, a sua plena eficácia.

Constata-se, do exposto, que a edição de uma súmula vinculante é rodeada de cautelas, previstas pelo legislador, de forma a não se permitir vinculação à tese jurídica pouco testada e debatida.

Sem embargo, não há como negar que a inauguração do instituto no ordenamento jurídico brasileiro constitucionalizou, ao lado da suspensão pelo Senado, mais um mecanismo no sentido de se conferir efeitos erga omnes e vinculantes a declarações incidentais de inconstitucionalidade proferidas pelo STF.

\footnotetext{
${ }^{67}$ A Lei 11.417/2006, que regulamentou o instituto, estendeu a legitimação também aos tribunais e aos Municípios, desde que, quantos aos últimos, a provocação se dê no âmbito de processo no qual sejam parte.

${ }^{68}$ Lei $11.417 / 2006$, art. $1^{\circ}$, $\S 2^{\circ}$. “O Procurador-Geral da República, nas propostas que não houver formulado, manifestar-se-á previamente à edição, revisão ou cancelamento de enunciado de súmula vinculante".

${ }^{69}$ Lei $11.417 / 2006$, art. $3^{\circ}, \S 2^{\circ}$. "No procedimento de edição, revisão ou cancelamento de enunciado da súmula vinculante, o relator poderá admitir, por decisão irrecorrível, a manifestação de terceiros na questão, nos termos do Regimento Interno do Supremo Tribunal Federal”.
} 


\subsection{Os entendimentos jurisprudenciais}

Em compasso com as alterações legislativas acima aduzidas, também a jurisprudência desenvolveu teses generalizadoras dos efeitos das decisões em controle difuso-incidental. Em verdade, muitas das mudanças na lei é que decorreram de construções jurisprudenciais.

A seguir, serão demonstrados alguns relevantes exemplos dessa notável inclinação jurisprudencial brasileira.

\subsubsection{Modulação dos efeitos da decisão}

Já foi enfatizado que a modulação dos efeitos das decisões do STF é uma forma de flexibilização à teoria da nulidade da norma inconstitucional. Apesar da coerência da teoria sob a perspectiva da supremacia da Constituição, a realidade demonstrou que, em algumas situações, os efeitos retroativos traziam consequências indesejáveis pelo próprio texto constitucional. ${ }^{70}$ Por isso, afirma-se que a modulação significa nada mais do que uma ponderação entre princípios igualmente protegidos pela Lei Maior.

Inicialmente aplicado pela jurisprudência, o mecanismo foi positivado no art. 27 da Lei $9.868 / 99^{71}$, que regulamenta o processo e julgamento das ações diretas.

Mas não tardou para que o STF começasse a aplicar a modulação temporal, também, aos julgados em sede de controle difuso-incidental. E, em alguns casos, esse emprego denotou, claramente, uma preocupação da Corte com consequências de sua decisão para além do caso concreto.

Foi o que se observou, por exemplo, no julgamento do $\mathrm{HC}$ $82.959 / \mathrm{SP}^{72}$, no qual o STF considerou inconstitucional a vedação da

\footnotetext{
${ }^{70}$ BARROSO, Luís Roberto. O controle de constitucionalidade no direito brasileiro. Op. cit. p. 47

${ }^{71}$ Lei 9.868/99, art. 27: "Ao declarar a inconstitucionalidade de lei ou ato normativo, e tendo em vista razões de segurança jurídica ou de excepcional interesse social, poderá o Supremo Tribunal Federal, por maioria de dois terços de seus membros, restringir os efeitos daquela declaração ou decidir que ela só tenha eficácia a partir de seu trânsito em julgado ou de outro momento que venha a ser fixado."
} 
progressão de regime, por violar a personalização da pena. Neste precedente, o Supremo optou, apesar de alguns votos contrários ${ }^{73}$, pela pronúncia de inconstitucionalidade com efeitos prospectivos. Assim fez por evidente preocupação de que, a partir daí, todas as pessoas já submetidas à norma inconstitucional requeressem a responsabilização do Estado por danos decorrentes de sua aplicação.

Ora, o receio da Corte quer significar que a decisão proferida teria o condão de refletir em todas as outras demandas em que debatidas a mesma questão jurídica.

Sob essa perspectiva, vale trazer comentário, na ocasião do julgamento, do então Min. Nelson Jobim:

"Se os colegas concordarem, gostaria de explicitar, como já fez o Min. Sepúlveda Pertence, que, na verdade, não estamos decidindo o caso concreto, estamos decidindo o regime de progressão ou não do sistema."

Diante disso, conclui-se que, no caso, a opção do Tribunal pela modulação de efeitos caracterizou, em certa medida, a aproximação dos dois modelos de controle, eis que se pretendeu conferir eficácia erga omnes a uma decisão prolatada em controle difuso-incidental.

Recentemente, o Supremo decidiu de modo semelhante na ADI 4029/DF. Referida ação direta visava à declaração de inconstitucionalidade da Lei 11.516/2007, que dispõe sobre a criação do Instituto Chico Mendes

\footnotetext{
${ }^{72}$ STF, DJE, 01 set 2006, HC 82.959/SP, rel. Min. Marco Aurélio

${ }^{73} \mathrm{O}$ voto da Min. Ellen Gracie refletiu muito bem o posicionamento contrário à modulação de efeitos das decisões em controle difuso-incidental. E, de certa forma, o não acolhimento dessa manifestação, pela maioria, reforçou a inclinação da Corte, ao menos àquela época, em conferir efeitos abstratos à pronúncia incidental de inconstitucionalidade. Confira-se parte do aludido voto: "Deixo de acolher as ponderações do Ministro Gilmar Mendes, que, com seu brilho invulgar de scholar, ainda assim não me consegue fazer aderir à sua proposição de uma declaração de inconstitucionalidade modulada, de sorte a apenas abranger as hipóteses futuras (pure prospective), ou seja, as sentenças ainda não proferidas, com ressalva dos casos já decididos. Se adotarmos tal solução, não poderemos aplicá-la ao paciente deste habeas corpus. Mas essa proposição nos cria um problema insolúvel. Tudo porque, em controle difuso, como é o caso presente, ou a declaração de inconstitucionalidade serve à solução da controvérsia ou ela nem se pode colocar. No controle difuso, não se produz interpretação constitucional, a menos que ela seja útil ao caso. Não se define o status de constitucionalidade de uma regra jurídica, senão quando ela esteja sendo aplicada ao caso concreto. E, se não for para ser aplicada ao caso presente, a declaração de inconstitucionalidade não tem substrato válido, já que esta não é hipótese de controle abstrato. (...). Para que a inconstitucionalidade da norma pudesse ser reconhecida com efeitos limitados, seria necessário que a Corte a analisasse em Ação Direta."
} 
de Conservação da Biodiversidade. O principal argumento da requerente assentou-se na inconstitucionalidade formal da referida lei, uma vez que a mesma resultou de conversão de medida provisória em cujo trâmite não foi observado o art. $62, \S 9^{\circ}, \mathrm{CRFB}$, que prevê a necessidade de parecer de comissão mista de deputados e senadores previamente à submissão da matéria ao plenário. Em verdade, tal prática seria legitimada por dispositivos da Resolução 1/2002 do Congresso Nacional, os quais dispensariam o parecer da comissão mista. Por isso, ao julgar a ADI, a Corte declarou, incidentalmente, a inconstitucionalidade da aludida Resolução, por afronta ao art. $62, \S 9^{\circ}, \mathrm{CRFB}$. Consequentemente, a decisão incidental funcionou como premissa lógica à declaração de inconstitucionalidade da própria Lei 11.516/2007, já que resultante de trâmite legislativo baseado no ato normativo reputado incompatível com a Constituição. $^{74}$

Ocorre que, no dia seguinte, o AGU suscitou questão de ordem demonstrando preocupação diante da declaração de inconstitucionalidade da Resolução 1/2002 do Congresso Nacional, tendo em vista o elevado número de medidas provisórias já convertidas em lei com base no mencionado ato, ou seja, sem a produção de parecer de comissão mista. Assim, requereu-se a modulação dos efeitos da decisão de inconstitucionalidade da Resolução e a fixação de um prazo para que o Congresso adaptasse o processo legislativo de tramitação de medidas provisórias.

Ora, verifica-se da própria pretensão do AGU de modular os efeitos da declaração de inconstitucionalidade da Resolução 1/2002 uma preocupação com a eficácia dessa decisão sobre outras leis que não àquela submetida ao exame do STF. Considerando-se que a decisão foi proferida em sede incidental, tal receio sequer teria razão de ser, já que a eficácia retroativa da inconstitucionalidade seria produzida apenas no caso concreto,

\footnotetext{
${ }^{74}$ Nesse primeiro momento, foi declarada a inconstitucionalidade da Lei $11.516 / 2007$ sem pronúncia de nulidade, pelo prazo de 24 meses, a fim de possibilitar a continuidade do Instituto Chico Mendes, por meio de convalidação a ser procedida nesse período.
} 
ou seja, tão somente em relação à Lei 11.516/2007. Tampouco residiria a preocupação em eventual suspensão do ato pelo Senado, uma vez que, segundo corrente majoritaríssima, essa suspensão produz efeitos meramente ex nunc, pelo que ficariam resguardadas, igualmente, as leis decorrentes de conversões anteriores.

Nada obstante, demonstrando o mesmo receio, a Corte acolheu a questão de ordem, atribuindo efeitos ex nunc a declaração incidental de inconstitucionalidade da Resolução 1/2002, resultando na conversão do julgamento da ADI de parcialmente procedente à improcedente. Vale dizer, produziu-se uma interpretação constitucional inaplicável ao caso sob exame. A preocupação concentrou-se, apenas, nas consequências para além do caso concreto: de um lado, que tal interpretação fosse utilizada somente para casos futuros semelhantes e, de outro, que todos os casos anteriores fossem resguardados de sua aplicabilidade, evitando-se uma enxurrada de novas ações. Essas considerações seriam típicas de interpretações constitucionais produzidas em controle concentrado. $\mathrm{Na}$ linha do entendimento esposado pela Min. Ellen Gracie no HC 82.959/SP, em controle difuso, não se define o status de constitucionalidade de uma norma se ela não estiver sendo aplicada ao caso concreto. O receio com a propositura de novas ações, questionando leis já há muito em vigor, não deveria pautar o entendimento do STF, porquanto suas conclusões deveriam se restringir ao caso levado a exame.

Trecho retirado do Informativo $n$. 657, STF bem demonstra como a mudança de posicionamento da Corte decorreu da preocupação com a ineficácia da Resolução 1/2002 para outras leis, já editadas, resultantes de conversão de medida provisória. Veja-se:

\footnotetext{
“A emissão de parecer, relativamente a medidas provisórias, por comissão mista de deputados e senadores antes do exame, em sessão separada, pelo plenário de cada

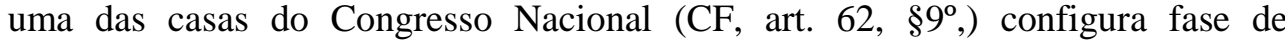
observância obrigatória no processo constitucional de conversão dessa espécie normativa em lei ordinária. Com base nesse entendimento e tendo em conta razões de segurança jurídica para a manutenção dos diplomas legais já editados com esse vício de tramitação, o Tribunal acolheu questão de ordem, suscitada pelo
} 
Advogado-Geral da União, para alterar o dispositivo do acórdão da presente ação direta apreciada em assentada anterior. Ato contínuo, em votação majoritária, julgou improcedente o pleito formulado, mas declarou, incidentalmente, com eficácia ex nunc, a inconstitucionalidade dos artigos $5^{\circ}$, caput, e $6^{\circ}, \S \S 1^{\circ}$ e $2^{\circ}$, da Resolução 1/2002, do Congresso Nacional."

\subsubsection{Manifesta improcedência de ADI diante de precedente em RE}

Outro entendimento do STF que corrobora a tendência à aproximação dos dois modelos de controle e que serve também de argumento aos adeptos da teoria da abstrativização foi revelado na ADI n. 4.071/DF.

Nessa ação direta, a Corte entendeu pela sua manifesta improcedência sob o fundamento de que a pretensão, nela veiculada, já havia sido apreciada pelo Pleno do Tribunal no julgamento de dois recursos extraordinários.

É o que consta da decisão do relator, o então Min. Carlos Alberto Menezes Direito, confirmada em agravo regimental:

“(...) Decido. A questão objeto da presente ação direta de inconstitucionalidade foi recentemente decidida pelo Plenário deste Supremo Tribunal Federal, em 17/9/2008, no julgamento dos recursos extraordinários de $n^{\circ}$ s 377.457 e 381.964 , ambos da relatoria do Ministro Gilmar Mendes. Naquela oportunidade, firmou-se o entendimento de que o conflito aparente entre lei ordinária e lei complementar não deveria ser resolvido pelo critério hierárquico, mas pela natureza da matéria regrada, de acordo com o que dispõe a Constituição Federal. (...) Claro, portanto, que a matéria objeto desta ação direta de inconstitucionalidade já foi inteiramente julgada pelo Plenário, contrariamente à pretensão do requerente, o que revela a manifesta improcedência da demanda. (...) com fulcro no art. $4^{\circ}$ da Lei $n^{\circ}$ $9.868 / 99$, indefiro a petição inicial. Publique-se." ${ }^{76}$

Ora, essa decisão demonstra, de forma bastante clara, que, para o STF - ao menos em sua composição quando de referido julgamento - não haveria diferenças substanciais entre as decisões proferidas numa ou noutra via de controle. Se entendesse ser necessária a provocação, em sede concentrada-principal, para que se estendessem os efeitos da decisão a terceiros, não deveria ter indeferido, de plano, a ação direta. Ao menos, não

\footnotetext{
${ }^{75}$ Disponível em <http://www.stf.jus.br>

${ }^{76}$ STF, DJE, 14 out 2010, ADI 4.071/DF, rel. Min. Carlos Alberto Menezes Direito.
} 
sob o argumento de a questão já ter sido debatida em recursos extraordinários.

Mais uma vez, portanto, o Tribunal externou posição compatível com a aproximação dos dois modelos de controle e, quiçá, com a teoria da abstrativização do controle difuso-incidental.

\subsubsection{Efeitos erga omnes e vinculantes atribuídos pelo STF às suas decisões em controle difuso-incidental}

Recentemente, observou-se, no âmbito da jurisprudência do STF, aquilo que seria o mais ousado movimento em direção à abstrativização do controle difuso-incidental. Em alguns importantes precedentes, a própria Corte atribuiu efeitos erga omnes e vinculantes, automáticos, a julgados proferidos nesta sede. Promoveu-se, nesses casos, verdadeira equiparação de efeitos dessas decisões aos efeitos produzidos em ações diretas. A principal ferramenta utilizada pelos Ministros, que assim se posicionaram, foi a aplicação da eficácia transcendente da fundamentação. ${ }^{77}$

\subsubsection{Eficácia transcendente da fundamentação}

O debate quanto a uma possível eficácia transcendente da fundamentação dos julgados se desenvolveu com a teoria da transcendência dos motivos determinantes, inicialmente aplicada ao controle concentradoprincipal. A sua ideia está no "reconhecimento de que a eficácia vinculante não só concerne à parte dispositiva, mas refere-se, também, aos próprios fundamentos determinantes ('ratio decidendi') do julgado declaratório de inconstitucionalidade emanado do Supremo Tribunal Federal." 7879

\footnotetext{
${ }^{77}$ Ressalte-se, entretanto, que tais julgados representaram um posicionamento ainda atípico, longe de estar pacificado. Em todos os precedentes verificados em que foi suscitada a eficácia transcendente da fundamentação, não se atingiu a unanimidade. Considerando-se, em especial, a troca de Ministros de tempos em tempos no STF, há a possibilidade de que a teoria não venha a vingar. Há, inclusive, precedentes negando a sua aplicação, como no julgamento da recente Rcl 11477 AgR/CE - Inf. 668/STF.

${ }^{78}$ Definição dada pelo Min. Celso de Mello no voto da ADI 3.345/DF
} 
O leading case a respeito do assunto foi a Reclamação $1.987 / \mathrm{DF}^{80}$, na qual se discutiu o emprego da teoria em relação a normas declaradas inconstitucionais em controle concentrado-principal.

Ocorre que, posteriormente, a Corte passou a discutir, também, a sua aplicação em relação aos fundamentos determinantes de declarações incidentais de inconstitucionalidade. E, apesar de extremamente controvertida no Tribunal, a teoria foi empregada em alguns julgados.

Note-se que a teoria foi desenvolvida para justificar a eficácia transcendente dos próprios fundamentos que embasem uma declaração de inconstitucionalidade. No controle difuso-incidental, não foi diferente. A discussão quanto a sua aplicação também se iniciou a partir da pretensão, de alguns Ministros, de estender os fundamentos que tivessem levado à Corte a decretar uma inconstitucionalidade, com a diferença de esta ter se dado em um incidente.

No entanto, já foi demonstrado, que, em controle difuso-incidental, a própria declaração de inconstitucionalidade é questão prejudicial no processo, não integrando o dispositivo da decisão e $\operatorname{sim}$ a sua fundamentação. Disso decorre a eficácia meramente inter partes da declaração incidental, que sequer faz coisa julgada. Em razão desses aspectos processuais, a eficácia transcendente da fundamentação tem sido invocada, em controle difuso-incidental, na intenção de se justificar uma extensão dos efeitos da própria declaração incidental a outros processos.

Passemos, então, a analisar alguns precedentes.

\subsection{RE 197.917/SP e ADIs 3.345/DF e 3.365/DF}

No julgamento do RE 197.917/SP, publicado em 27.02.2004, o STF decidiu, incidenter tantum, pela inconstitucionalidade de Lei Orgânica do

\footnotetext{
${ }^{79}$ Patrícia Perrone alerta que a nomenclatura dada à teoria não é muito feliz, uma vez que não são os motivos da decisão em si que vinculam (uma mesma decisão pode ter vários fundamentos) e sim o comando geral deles extraído, a exegese fixada pela Corte. MELLO, Patrícia Perrone Campos. Op. cit., p. 156-157

${ }^{80}$ STF, DJE, 30 abr. 2010, ADI 1.987/DF, rel. Min. Gilmar Mendes.
} 
Município de Mira Estrela, que estabelecia o número de vereadores a compor a Câmara Municipal.

Baseado nessa decisão, o TSE editou a Resolução n. 21.702/2004, adotando, expressamente, para as eleições de 2004, o posicionamento da Suprema Corte no aludido recurso extraordinário. ${ }^{81}$ Através da Resolução, o TSE considerou inconstitucionais todas as leis orgânicas municipais que, assim como aquela de Mira Estrela, fixassem o número de vereadores no Município. O mencionado ato normativo nada menos fez do que generalizar os efeitos da decisão do Supremo, tendo em conta os fundamentos ali apresentados. $^{82}$

Assim, foram propostas duas ações diretas de inconstitucionalidade (ADIs 3.345/DF e 3.365/DF) contra a Resolução n. 21.702/2004, entendendo que o ato normativo, ao extrapolar os limites dos efeitos de decisão emanada em controle difuso-incidental, teria violado a autonomia municipal e a separação de poderes.

No entanto, as duas ADIs foram julgadas improcedentes, por maioria, pela Suprema Corte. ${ }^{83}$ E, em seu voto, o relator, Min. Celso de Mello, destacou, justamente, o efeito transcendente dos motivos determinantes da declaração de inconstitucionalidade proferida no RE 197.917/SP. A Resolução do TSE, segundo o ministro, teria preservado a força normativa da Constituição.

Registre-se importante passagem do voto em comento:

\footnotetext{
${ }^{81}$ Este o teor dos arts. $1^{\circ}$ e $2^{\circ}$ da Resolução em comento: “O Tribunal Superior Eleitoral, no uso das atribuições que lhe confere o art. 23, IX, do Código Eleitoral, resolve expedir a seguinte Instrução: Art. $1^{\circ}$ Nas eleições municipais deste ano, a fixação do número de vereadores a eleger observará os critérios declarados pelo Supremo Tribunal Federal no julgamento do RE nº 197.917, conforme as tabelas anexas. Parágrafo único. A população de cada município, para os fins deste artigo, será a constante da estimativa do Instituto Brasileiro de Geografia e Estatística (IBGE) divulgada em 2003. Art. $2^{\circ}$ Até $1^{\circ}$ de junho de 2004, o Tribunal Superior Eleitoral verificará a adequação da legislação de cada município ao disposto no art. $1^{\circ}$ e, na omissão ou desconformidade dela, determinará o número de vereadores a eleger."

${ }^{82}$ No próprio julgamento do RE 197.917/SP, os Ministros demonstraram a preocupação com que a matéria fosse uniformizada pelo TSE para as eleições que se seguiriam. O debate foi transcrito pelo Min. Celso de Mello em seu voto nas ADIs 3.345 e 3.365, donde percebe-se a intenção de alguns ministros de que os fundamentos da decisão produzissem efeitos para além do caso concreto.

${ }^{83}$ Apenas ficou vencido o Min. Marco Aurélio.
} 


\begin{abstract}
"Na realidade, o Tribunal Superior Eleitoral, expondo-se à eficácia irradiante dos motivos determinantes que fundamentaram o mencionado julgamento plenário do RE 197.917/SP, Rel. Min. Maurício Corrêa, submeteu-se, na elaboração do ato ora questionado, ao princípio da força normativa da Constituição, que representa diretriz relevante no processo de interpretação concretizante do texto constitucional (...).

Torna-se relevante salientar, na linha do que destacou o eminente Ministro Gilmar Mendes, que esta Suprema Corte deu efeito transcendente aos próprios motivos determinantes que deram suporte ao julgamento plenário do RE 197.917/SP. Esse aspecto assume relevo indiscutível, pois permite examinar a presente controvérsia constitucional em face do denominado efeito transcendente dos motivos determinantes subjacentes à decisão declaratória de inconstitucionalidade proferida no julgamento plenário do RE 197.917/SP, Rel. Min. Maurício Corrêa, especialmente em decorrência das intervenções dos eminentes Ministros Nelson Jobim, Gilmar Mendes e Sepúlveda Pertence. Cabe referir, em particular, neste ponto, a intervenção do eminente Ministro Gilmar Mendes, que ressaltou a aplicabilidade, ao E. Tribunal Superior Eleitoral, do efeito vinculante emergente da própria 'ratio decidendi' que motivou o julgamento do precedente mencionado." $\$ 84$
\end{abstract}

Nota-se, no caso, que a eficácia transcendente foi atribuída aos fundamentos que calcaram a própria decisão incidental e não a esta em si. Tratou-se, assim, de típica aplicação da teoria da transcendência dos motivos determinantes ao controle difuso-incidental. Destarte, proporcionou-se que os efeitos de um único julgado refletissem sobre todos os outros semelhantes.

\title{
2.4.3.1.2. Mls 670/ES, 708/DF e 712/PA
}

Os Mandados de Injunção coletivos n. 670, 708 e 712 foram impetrados por sindicatos visando o reconhecimento da omissão legislativa em relação à regulamentação do direito de greve dos servidores públicos civis (art. 37, VII, $\mathrm{CRFB}^{85}$ ).

O julgamento desses três processos, em 2007, representou, inclusive, uma mudança de entendimento da Suprema Corte em matéria de mandado de injunção. Pela primeira vez, o Tribunal adotou uma posição concretista e

\footnotetext{
${ }^{84}$ STF, DJU, 08 set. 2005, ADI 3.345/DF, rel. Min. Celso de Mello.

${ }^{85}$ CRFB, art. 37: “A administração pública direta e indireta de qualquer dos Poderes da União, dos Estados, do Distrito Federal e dos Municípios obedecerá aos princípios de legalidade, impessoalidade, moralidade, publicidade e eficiência e, também, ao seguinte: VII - o direito de greve será exercido nos termos e nos limites definidos em lei específica."
} 
decidiu pela aplicação analógica do regime jurídico de greve dos trabalhadores da iniciativa privada a servidores públicos.

No que toca à aproximação dos dois modelos de controle e à teoria da abstrativização, a importância de tais julgados está no fato de que a Corte afastou os efeitos da omissão legislativa em caráter geral. Vale dizer: reconheceu-se a inconstitucionalidade da omissão legislativa em relação a todos os servidores públicos civis e não apenas às categorias representadas pelos sindicatos que haviam proposto as demandas. A bem da verdade, ao que efetivamente se conferiu efeitos generalizantes, foi aos dispositivos das decisões, que determinaram a aplicação analógica da Lei 7.783/89. Mas, forçoso reconhecer que, ao assim proceder, a Corte estendeu os efeitos da própria declaração de inconstitucionalidade por omissão (premissa lógica da decisão) a todos os servidores públicos civis.

Em que pese ter havido votos contrários à extensão dos efeitos da decisão, não foi essa a posição prevalecente. ${ }^{86}$ Trecho do voto do Min. Eros Grau, relator no MI 712/PA, em que cita o doutrinador José Ignácio

\footnotetext{
${ }^{86}$ Neste ponto, ficaram vencidos os Ministros Marco Aurélio, Joaquim Barbosa e Ricardo Lewandowski. Em verdade, exceto pelo voto do Min. Gilmar Mendes, os votos dos demais Ministros que seguiram o relator não traduziram, expressamente, concordância quanto à atribuição de efeitos erga omnes à decisão. Mas, ao que tudo indica, foi esse o entendimento, uma vez que os Ministros acataram a decisão do relator, votando pela "aplicação da Lei 7.783/89 aos servidores públicos civis" (sem fazer restrições aos servidores da categoria representada). Não à toa, os Ministros Ricardo Lewandowski, Joaquim Barbosa e Marco Aurélio consignaram, em seus votos, discordância em relação à atribuição de efeitos erga omnes à decisão do mandado de injunção, votando pela aplicação da Lei 7.783/89 aos servidores do Poder Judiciário do Pará, categoria representada pelo sindicato impetrante. Inclusive, o Min. Joaquim Barbosa propôs a edição de súmula vinculante para que fossem conferidos os efeitos generalizantes pretendidos. No entanto, como se extrai do Informativo n. 485, STF, os três Ministros ficaram vencidos, do que se depreende que a decisão final, de fato, foi pela extensão da decisão a todos os servidores públicos civis. Veja-se trecho extraído do repositório de jurisprudência: "Por fim, concluiu-se que, sob pena de injustificada e inadmissível negativa de prestação jurisdicional nos âmbitos federal, estadual e municipal, seria mister que, na decisão do writ, fossem fixados, também, os parâmetros institucionais e constitucionais de definição de competência, provisória e ampliativa, para apreciação de dissídios de greve instaurados entre o Poder Público e os servidores com vínculo estatutário. Dessa forma, no plano procedimental, vislumbrou-se a possibilidade de aplicação da Lei 7.701/88, que cuida da especialização das turmas dos Tribunais do Trabalho em processos coletivos. No MI 712/PA, prevaleceu o voto do Min. Eros Grau, relator, nessa mesma linha. Ficaram vencidos, em parte, nos três mandados de injunção, os Ministros Ricardo Lewandowski, Joaquim Barbosa e Marco Aurélio, que limitavam a decisão à categoria representada pelos respectivos sindicatos e estabeleciam condições específicas para o exercício das paralisações. Também ficou vencido, parcialmente, no MI 670/ES, o Min. Maurício Corrêa, relator, que conhecia do writ apenas para certificar a mora do Congresso Nacional."
} 
Botelho de Mesquita, bem demonstra a preocupação do então Ministro em se conferir efeitos gerais à decisão, com base no postulado da isonomia:

\begin{abstract}
"Fixados estes limites desponta o problema da compreensão da hipótese da norma que será supletivamente formulada pelo tribunal. Deverá ela regular apenas o caso concreto submetido ao tribunal, ou abranger a totalidade dos casos constituídos pelos mesmos elementos objetivos, embora entre sujeitos diferentes? Dentre essas alternativas, é de se optar pela última, posto que atividade normativa é dominada pelo princípio da isonomia, que exclui a possibilidade de se criarem tantas normas regulamentadoras diferentes quantos sejam os casos concretos submetidos ao mesmo preceito constitucional. Também aqui é preciso ter presente que não cumpre ao tribunal remover um obstáculo que só diga respeito ao caso concreto, mas a todos os casos constituídos pelos mesmos elementos objetivos". ${ }^{87}$
\end{abstract}

É de se ver que, novamente, a Corte posicionou-se no sentido da aproximação dos dois modelos de controle, ao dar efeitos transcendentes à declaração incidental de inconstitucionalidade por omissão.

\title{
2.4.3.1.3. HC 82.959/SP e Rcl $4.335 / A C$
}

O HC 82.959/SP foi um dos precedentes que mais suscitou polêmicas no que tange à eficácia transcendente da fundamentação. No julgamento desse processo, o STF declarou, incidentalmente, a inconstitucionalidade do $\S 1^{\circ}$ do art. $2^{\circ}$ da Lei $8.072 / 90$, que vedava a progressão de regimes a condenados pela prática de crimes hediondos. Originalmente, portanto, a declaração de inconstitucionalidade proferida somente produziria efeitos entre as partes do processo, a não ser que houvesse suspensão da norma pelo Senado Federal.

Sob esse argumento, Juiz de Direito da Vara de Execuções Penais da Comarca de Rio Branco-AC, continuou aplicando o $\S 1^{\circ}$ do art. $2^{\circ}$ da Lei 8.072/90 nos casos que lhe eram submetidos. Afixou, inclusive, recado no quadro de avisos do juízo comunicando que a norma não havia sido suspensa pelo Senado Federal. Contra essas decisões, a Defensoria Pública do Acre ajuizou a Reclamação 4.335/AC, alegando ofensa à autoridade da

\footnotetext{
${ }^{87}$ STF, DJE, 23 nov. 2007, MI 712/PA, rel. Min. Eros Grau.
} 
decisão da Corte no HC 82.959/SP. Veja-se que a Defensoria pretendeu estender os efeitos da declaração de inconstitucionalidade, automaticamente, a todos os casos semelhantes.

O relator, Min. Gilmar Mendes, não só conheceu da reclamação (indicando a força erga omnes e vinculante automática da decisão no HC 82.959), como proferiu voto pela sua procedência, no que foi seguido pelo Min. Eros Grau. O principal fundamento do relator foi o de que ocorreu mutação constitucional do art. 52, X, CRFB. Sendo assim, as declarações de inconstitucionalidade proferidas pelo STF, ainda que incidenter tantum, teriam efeitos erga omnes e vinculantes automáticos, sendo o papel da resolução senatorial de mera publicidade.

Conforme verifica Pedro Lenza, o voto do Ministro representou a intenção de consagrar a tese da transcendência da ratio decidendi, posto, justamente, que a decisão do incidente de inconstitucionalidade integra a fundamentação da decisão final e não o seu dispositivo. ${ }^{88}$

O aludido voto foi alvo de muitas críticas na doutrina, sobretudo, pela pretensa mutação constitucional do art. 52, X, CRFB, mas também pela própria intenção de se conferir efeitos erga omnes e vinculantes automáticos à decisão incidental.

Votaram contrariamente os Min. Sepúlveda Pertence e Joaquim Barbosa, para os quais já existiria instrumento ao alcance do Supremo para a atribuição de tais efeitos às suas decisões em controle difuso: a súmula vinculante. O julgamento foi suspenso por pedido de vista do Min. Ricardo Lewandowski.

Infelizmente, após isso, a apreciação do caso teve a sua importância esvaziada, uma vez que foi editada a Súmula Vinculante n. $26^{89}$, estabelecendo a inconstitucionalidade do $\S 1^{\circ}$ do art. $2^{\circ}$ da Lei 8.072/90. Não

\footnotetext{
${ }^{88}$ LENZA, Pedro. Op. cit., p. 188

${ }^{89}$ STF, Súmula Vinculante n. 26: "Para efeito de progressão de regime no cumprimento de pena por crime hediondo, ou equiparado, o juízo da execução observará a inconstitucionalidade do art. $2^{\circ}$ da Lei n. 8.072, de 25 de julho de 1990, sem prejuízo de avaliar se o condenado preenche, ou não, os requisitos objetivos e subjetivos do benefício, podendo determinar, para tal fim, de modo fundamentado, a realização de exame criminológico."
} 
se obteve, assim, uma conclusão precisa da Corte sobre o tema. Todavia, a própria aprovação do verbete vinculante pareceu indicar a adoção - mais conservadora - dos argumentos expostos pelos Min. Sepúlveda Pertence e Joaquim Barbosa.

Ainda assim, não há dúvidas de que se trata de importante precedente para a teoria da abstrativização do controle difuso-incidental. A partir dele, ampliou-se na doutrina o debate acerca da possibilidade ou não de equiparação dos efeitos do controle difuso-incidental aos do controle concentrado-principal. 


\section{Capítulo 3}

\section{Efeitos}

\subsection{Redefinição do modelo de controle de constitucionalidade brasileiro}

\subsubsection{Papel do Senado Federal: mutação constitucional?}

Viu-se que diversos mecanismos, gradativamente desenvolvidos pela jurisprudência e introduzidos pelo legislador, conferiram, senão efeitos vinculantes, ao menos, eficácia erga omnes aos juízos incidentais do STF acerca da constitucionalidade de uma norma. A súmula vinculante, por exemplo, é constitucionalmente prevista e possui efeitos vinculativos expressos, assemelhando-se à resolução senatorial. Todos esses instrumentos contribuíram para aproximar os dois modelos de controle de constitucionalidade no Brasil, ainda que não os tenha equiparado totalmente, eis que a produção dos referidos efeitos não se dá de forma automática.

Mas é de se notar que, ainda que indiretamente, foi sendo atribuída, ao Supremo, parte do poder antes conferido apenas ao Senado Federal. E, além de todos os mecanismos supracitados, há o entendimento, de muitos autores, de que a atribuição conferida ao Senado residiria, exclusivamente, em razões históricas não mais existentes. ${ }^{90} \mathrm{~A}$ intervenção da casa legislativa teria sido necessária em uma época em que só havia o controle difusoincidental no Brasil.

Diferentemente do direito norte-americano - de onde importamos o modelo -, a tradição do civil law, não confere efeitos gerais e vinculantes às decisões judiciais da Suprema Corte no exame de casos concretos. E teria

\footnotetext{
${ }^{90}$ Essa parece ser, por exemplo, a posição de Luís Roberto Barroso, ainda que não concorde com a ocorrência de mutação constitucional do art. 52, X, CRFB. Cf. BARROSO, Luís Roberto. Op. cit., p. $154-157$
} 
sido diante das indesejáveis consequências à isonomia, segurança jurídica e racionalização jurisdicional que isto provocaria $^{91}$, que se atribuiu, ao Senado, a competência de suspender a lei declarada incompatível com a Constituição.

Todavia, a inauguração do controle concentrado-principal - e toda a ênfase a ele conferida -, dando ao STF o poder de, automaticamente, extirpar uma lei inconstitucional do ordenamento jurídico, teria tornado a função senatorial um anacronismo. Não seria razoável que idênticas decisões do Pleno do STF tenham alcances diferentes, dependendo da via em que proferidas. ${ }^{92}$

Como se não bastasse, a necessária intervenção do Senado para conferir efeitos erga omnes às decisões do STF em controle difusoincidental se mostraria inadequada diante de novas técnicas introduzidas na realidade jurisdicional brasileira. Seriam exemplos a interpretação conforme a Constituição e a declaração de inconstitucionalidade sem redução de texto. Nelas, mantém-se intacto o texto normativo, de modo que a resolução senatorial não se presta a estender seus efeitos.

Mencione-se, ainda, a aceitação, pela jurisprudência, do controle de constitucionalidade em ações coletivas. ${ }^{93}$ Muitas vezes, a declaração incidental de inconstitucionalidade, nesse tipo de ação, tornaria a norma automaticamente inútil. Isto porque, não seriam raros os casos em que o dispositivo impugnado teria como únicos destinatários os substituídos pelo legitimado coletivo.

\footnotetext{
${ }^{91}$ Corroborando o afirmado, Teori Albino Zavascki: "Estabelecido que a decisão incidental sobre constitucionalidade tem eficácia limitada ao caso concreto, tornou-se necessária a adoção de mecanismos para preservar a segurança jurídica e a isonomia e evitar, nos tribunais, a repetição desnecessária do julgamento da mesma questão. Assim, com o correr do tempo, várias importantes modificações nesse sentido foram sendo produzidas no sistema, todas elas com indisfarçável finalidade de ampliar a eficácia dessas decisões, mormente quando proferidas pelo Supremo Tribunal Federal, guardião da Constituição. As mais significativas foram: (a) habilitar o Senado a suspender a execução das normas declaradas inconstitucionais pelo STF..." Cf. ZAVASCKI, Teori Albino. Op. cit., p. 28

92 BARROSO, Op. Cit., p. 157

93 Antes inadmissível, o controle difuso-incidental em ações coletivas passou a ser aceito pela jurisprudência do STF.
} 
Face a tudo isso, no intuito de ir além do que, até então, teriam ido os mecanismos existentes e equiparar, de vez, os efeitos do controle difusoincidental aos do controle concentrado-principal, parte da doutrina e jurisprudência, capitaneada pelo Min. Gilmar Mendes, passou a sustentar a ocorrência de mutação constitucional do art. 52, X, CRFB. A competência do Senado, numa leitura atual do dispositivo, seria, tão somente, a de dar publicidade à decisão do STF, a qual teria, por si só, eficácia erga omnes e vinculante automática. ${ }^{94}$

Entretanto, após proferir voto, na Reclamação 4.335/AC, proclamando esse entendimento, o Min. Gilmar Mendes foi duramente criticado, por parcela significativa da doutrina, que entendia ser inconstitucional a ideia de mutação do art. 52, X, CRFB.

A principal crítica foi a de que a pretensão esbarraria na literalidade do dispositivo constitucional. E a mutação constitucional tem como um de seus limites as possibilidades semânticas do relato da norma, sob pena de se violar a soberania popular e, por conseguinte, o poder constituinte. ${ }^{95}$

Lênio Luiz Streck, Marcelo Andrade Cattoni de Oliveira e Martonio Mont'Alverne Barreto Lima, em artigo crítico à tese mutacional, asseveraram que, ao contrariar a literalidade da norma, estar-se-ia enfraquecendo a própria força normativa da Constituição. ${ }^{96}$ Apontaram, ainda, não haver qualquer dispositivo constitucional que autorize o STF a operar a pretendida sistemática. Se assim o fizer, extrapolará as competências que lhe foram constitucionalmente previstas. Sob essa perspectiva, frisaram que, “em determinadas situações, mutação

\footnotetext{
${ }^{94}$ MENDES, Gilmar Ferreira. O Papel do Senado Federal no Controle de Constitucionalidade. Op. cit., p. 29-30

${ }^{95}$ Nesse sentido, define Luis Roberto Barroso: “....a mutação constitucional há de se estancar em dois limites: a) a possibilidade semântica do relato da norma, vale dizer, os sentidos possíveis do texto que está sendo interpretado ou afetado; e b) a preservação dos princípios fundamentais que dão identidade àquela específica Constituição (...). As mutações que contrariem a Constituição podem certamente ocorrer, gerando mutações inconstitucionais.” Cf. BARROSO, Luís Roberto. Curso de Direito Constitucional Contemporâneo: os conceitos fundamentais e a construção do novo modelo. $3^{\mathrm{a}}$ ed. São Paulo: Saraiva, 2011. p. 150-151

${ }^{96}$ STRECK, Lênio Luiz et. al. A Nova Perspectiva do Supremo Tribunal Federal sobre o Controle Difuso: Mutação constitucional e Limites da Legitimidade da Jurisdição Constitucional. p. 11. Disponível em <http://www.mundojuridico.com.br〉. Acesso em 17 de julho de 2012.
} 
constitucional pode significar, equivocadamente, a substituição do poder constituinte pelo Poder Judiciário.” 97

Os mesmos autores, refutando, também, os argumentos de que o art. 52, $\mathrm{X}, \mathrm{CRFB}$ se assentaria unicamente em razões históricas, sustentaram a importância do dispositivo como instrumento de legitimação democrática.

Veja-se, nesse sentido, a seguinte passagem da mencionada obra:

"Na verdade, há uma questão que se levanta como condição de possibilidade na discussão acerca da validade (e da força normativa) do art. 52, X, da Constituição do Brasil. Trata-se de uma questão paradigmática, uma vez que sua ratificação (o que vem sendo repetido pelo menos desde 1934), em uma Constituição dos tempos de Estado Democrático de Direito, dá-se exatamente pela exigência democrática de participação da sociedade no processo de decisão acerca da (in) constitucionalidade de uma lei produzida pela vontade geral." $" 98$

Igualmente, haveria uma relevância da norma atinente ao federalismo. Essa a conclusão extraída de outra passagem do escrito doutrinário, in verbis:

"Espaço de representação política da Federação, ao Senado Federal foi atribuída a competência do art. 52, X da CF porque, racionalmente, somente a um organismo da Federação é que poderia recair a autoridade para suspensão de instrumentos normativos, por exemplo, oriundos de outros entes da Federação, como Estados, Distrito Federal ou Municípios, em razão, especialmente, da amplamente solidificada sistemática de controle de constitucionalidade a inadmitir controle concentrado de espécie normativa municipal diretamente no Supremo Tribunal Federal. Tem-se, então, uma dupla acepção de democracia: a que parte do controle reflexo do povo na eleição de representantes dos entes federados e o trato e o equilíbrio necessários à harmonização do sistema federativo brasileiro." 99

Percebe-se, dessa forma, que a pretensa mutação constitucional do art. 52, X, CRFB encontrou fortes resistências. Também os Min. Joaquim Barbosa e Sepúlveda Pertence discordaram da referida tese em seus votos na $\operatorname{Rcl} 4.335 / A C$.

Pelas razões apontadas, outros autores preferem entender que a declaração de inconstitucionalidade em controle difuso-incidental possui efeitos gerais, porém, vincula apenas as partes. O Senado ainda teria o

\footnotetext{
${ }^{97}$ Ibid., p. 15-17

${ }^{98}$ Ibid., p. 15

${ }^{99}$ Ibid., p. 12
} 
importante papel de retirar a norma do ordenamento jurídico e, assim, tornar os efeitos da decisão vinculantes a todas as pessoas. Destarte, essas decisões não teriam eficácia normativa, mas impositiva intermediária.

Confiram-se, nessa linha, as lições de Hugo de Brito Machado:

"Tais decisões, tanto as do Supremo Tribunal Federal como as dos demais tribunais do País, colocam-se em situação intermediária entre as decisões proferidas pelo Poder Judiciário nas questões em geral, e aquelas proferidas pelo Supremo Tribunal Federal no controle concentrado de constitucionalidade. Elas produzem efeito vinculante entre as partes no caso concreto porque se integram na decisão do caso concreto, como fundamento desta. E produzem também efeitos gerais, embora não vinculantes. Efeitos gerais que não tornam desnecessária a provocação do Senado Federal para que suspenda a vigência do dispositivo declarado inconstitucional, porque tal suspensão acrescentará o efeito de irretratabilidade ao extirpar do ordenamento jurídico a norma declarada inconstitucional." 100

E mesmo autores que parecem admitir a possibilidade de eventual equiparação dos efeitos da decisão em controle difuso-incidental aos das decisões em ações diretas, afirmam que o caminho para a sua obtenção não pode ser a mutação constitucional. Seria necessária, para isso, a manifestação do constituinte reformador. É como parece a Pedro Lenza:

\begin{abstract}
"Assim, na medida em que a análise da constitucionalidade da lei no controle difuso pelo STF não produz efeito vinculante, parece que somente mediante necessária reforma constitucional (modificando o art. 52, X, e a regra do art. 97) é que seria possível assegurar a constitucionalidade dessa nova tendência - repitase, bastante 'atraente' — da transcendência dos motivos determinantes no controle difuso, com caráter vinculante." 101
\end{abstract}

Conforme relatado no Capítulo 2, o advento da Súmula Vinculante n. 26 impediu que se extraísse posição precisa da Corte sobre o assunto na Rcl 4.335/AC. Mas, a edição do enunciado sumular pareceu indicar que a tese mutacional não encontrou respaldo entre os demais membros do Supremo, exceto pelo Min. Eros Grau, que ainda quando do julgamento, proferiu voto acompanhando o relator.

\footnotetext{
${ }^{100}$ MACHADO, Hugo de Brito apud MELLO, Patrícia Perrone Campos. Op. cit., p. 93

${ }^{101}$ LENZA, Pedro. Op. cit., p. 189
} 


\subsubsection{Recurso extraordinário: controle abstrato disponível ao cidadão?}

É cediço que o recurso extraordinário, apesar de instrumento do controle difuso-incidental - em que a questão constitucional é subjacente a um caso concreto -, presta-se à discussão de questões eminentemente de direito, o que, por si só, lhe confere um caráter mais objetivo. Nesse sentido, vigora, há muito, a Súmula 279 do STF. ${ }^{102}$

Mas, tem-se notado, na tendência à aproximação entre os dois modelos de controle, que o recurso extraordinário vem assumindo feições ainda mais objetivas. Já se falou da repercussão geral e da sistemática de julgamento dos recursos repetitivos.

Também acerca desse fenômeno, Fredie Didier Jr. identificou alguns precedentes do STF em que a Corte (i) admitiu a manifestação de amicus curiae no julgamento, (ii) dispensou o requisito do prequestionamento para fixar tese da Corte em matéria de controle de constitucionalidade e (iii) admitiu a causa de pedir (recursal) aberta, para julgar de acordo com fundamentos diversos dos suscitados pela parte. ${ }^{103}$ Tais precedentes apontariam, igualmente, para a intenção de se atribuir, à decisão do recurso extraordinário, eficácia para além das partes envolvidas no litígio.

Disso, há que se atentar para um importante efeito. Caso a teoria da abstrativização venha, eventualmente, a se consolidar no ordenamento jurídico, o cidadão passaria, então, a ser legitimado ao controle abstrato de leis ou atos normativos por meio, sobretudo, do recurso extraordinário.

Esse alerta foi feito por alguns profissionais que escreveram sobre o tema. Vejam-se os comentários de Gervázio Fernandes de Serra Júnior, Procurador do Estado de Sergipe:

\footnotetext{
${ }^{102}$ STF, Súmula n. 279: "Para simples reexame de prova não cabe recurso extraordinário".

${ }_{103}$ JR. DIDIER, Fredie. Transformações do recurso extraordinário. In: WAMBIER, Teresa Arruda; JR. NERY, Nelson. Aspectos Polêmicos e Atuais dos Recursos Cíveis e Assuntos Afins, vol. 10, São Paulo: Revista dos Tribunais, 2006, p. 109-112
} 
"Devido a isso, atualmente, há diversas discussões entre doutrinadores processualistas sobre essa nova tendência 'abstrata' presente nos efeitos dos recursos extraordinários, fazendo surgir a possibilidade de, paulatinamente e indiretamente, ampliar o rol de legitimados a proporem ações que visem controlar, abstratamente, a constitucionalidade de leis ou atos normativos, posto que os efeitos de uma decisão num processo subjetivo não mas ficam adstritos, somente, às partes integrantes do litígio, mas, sim, estendem-se a diversas outras causas nas quais se discutem questões semelhantes. Não se pretende demonstrar, com isso, que o rol de legitimados do artigo 103 da Lei Maior está sofrendo alteração, mas não se pode olvidar que as consequências trazidas por essas novas possibilidades defendidas pela Suprema Corte acabam, ainda que indiretamente, possibilitando tal interpretação."

Nessa mesma linha de raciocínio, e opinando ser benéfico tal efeito, o Procurador da Fazenda Nacional, Jonatas Vieira de Lima:

"[O] controle de constitucionalidade em tese estaria acessível aos cidadãos comuns, tendo em vista que não se exigiria legitimação específica para a ação, assegurando de forma mais abrangente a supremacia e a rigidez constitucionais". ${ }^{105}$

Neste particular, vale mencionar que José Afonso da Silva, após elencar o novo rol de legitimados às ações diretas, lamentou o fato de a Constituição de 1988 não ter ali incluído o cidadão. ${ }^{106}$ Ao que parece, eventual equiparação entre os dois modelos de controle acabaria por atender, indiretamente, ao anseio do respeitável doutrinador.

\subsection{Ampliação do uso da Reclamação}

Efeito de eventual consolidação da teoria da abstrativização, que é motivo de preocupação para alguns ministros e doutrinadores, é a possibilidade de que se amplie, de forma desmedida, o uso da reclamação constitucional.

\footnotetext{
${ }^{104}$ SERRA JÚNIOR, Gervázio Fernandes de. apud SOUZA, Eduardo Francisco. Op. cit., p. 9

${ }^{105}$ LIMA, Jonatas Vieira de. apud SOUZA, Eduardo Francisco. Op. cit., p. 9

${ }^{106}$ Após elencar o novo rol de legitimados trazido pela CRFB/88, o autor comentou: "Pena não ter incluído o cidadão". Cf. SILVA, José Afonso. Curso de Direito Constitucional Positivo. $27^{\mathrm{a}}$ ed. São Paulo: Malheiros Editores, 2006. p. 51
} 
$\mathrm{O}$ instituto, previsto no art. $102, \mathrm{I}, 1, \mathrm{CRFB}^{107}$, tem como objetivo a preservação da competência e da autoridade das decisões do Supremo.

Em relação às decisões proferidas em controle concentradoprincipal, o entendimento atual é o de que qualquer interessado é legitimado para a sua propositura, mesmo não tendo sido parte na ação direta. ${ }^{108}$

Já no que toca às decisões proferidas em controle difuso-incidental, pela concepção originária desse modelo, somente podem propor a ação constitucional aqueles que participaram do litígio, já que os efeitos vinculantes da decisão se produzem apenas inter partes.

No entanto, foi visto, no Capítulo 2, que diversos mecanismos conferiram eficácia geral aos julgados da Suprema Corte em controle difuso-incidental, aproximando-o do controle concentrado-principal. Diante disso, surgiram muitas controvérsias doutrinárias acerca dos efeitos vinculantes ou não desses mesmos julgados, ou seja, se haveria, ou não, uma obrigatoriedade dos demais órgãos judiciais e até da Administração Pública em seguí-los. Sem dúvidas, o reflexo direto de eventual vinculação seria o cabimento de reclamação constitucional, por terceiros, que não tenham participado do processo. E não foram poucos os autores que assim se posicionaram.

Ao escrever sobre os mecanismos legislativos e judiciais generalizantes das decisões incidentais do Supremo, opinou Fredie Didier Jr.:

\footnotetext{
"Tudo isso leva-nos a admitir a ampliação do cabimento da reclamação constitucional, para abranger os casos de desobediência a decisões tomadas pelo Pleno do STF em controle difuso de constitucionalidade, independentemente da existência de enunciado sumular vinculante. É certo, porém, que não há previsão expressa nesse sentido (fala-se de reclamação por desrespeito à 'súmula vinculante' e à decisão em ação de controle concentrado de constitucionalidade). Mas a nova feição que vem assumindo o controle difuso de constitucionalidade, quando feito pelo STF, permite que se faça essa interpretação extensiva, até

107 CRFB, art. 102: “Compete ao Supremo Tribunal Federal, precipuamente, a guarda da Constituição, cabendo-lhe: I - processar e julgar, originariamente: 1) a reclamação para a preservação de sua competência e garantia da autoridade de suas decisões."

${ }^{108}$ Assevera Patrícia Perrone que esse entendimento é relativamente recente, tendo decorrido de decisão proferida no Ag. Reg. na Rcl n. 1.1880-6/SP, rel. Min. Maurício Corrêa, j. 01 nov. 2002, DJ: 19 mar. 2004. Cf. MELLO, Patrícia Perrone Campos. Op. cit., p. 94
} 
mesmo como forma de evitar decisões contraditórias e acelerar o julgamento das demandas". ${ }^{109}$

No mesmo sentido, como já referido no item 2.2., encontram-se as posições de Nagib Slaibi Filho, Gilmar Ferreira Mendes e Teori Albino Zavascki. ${ }^{110}$

Esse entendimento, contudo, não encontra reflexo firme na jurisprudência. Ao menos, não, por ora. O STF continua a externar o seu entendimento tradicional de que a reclamação é medida excepcionalíssima. Por isso, tem se recusado a conhecer de reclamações que invoquem, como paradigma, julgado proferido em sede de controle difuso-incidental, do qual o reclamante não tenha sido parte. A exceção está, é claro, pela súmula vinculante, em que é expresso o cabimento do manejo processual.

A maioria dos argumentos da Corte reside em questões de índole formal, como os limites objetivos e subjetivos do efeito vinculante ou a impossibilidade de que a ação seja utilizada como sucedâneo recursal.

Nesse contexto, Patrícia Perrone traz um dado importante. ${ }^{111}$ Essa resistência teria, também, como pano de fundo, uma preocupação da Corte em que possa ser comprometida a própria viabilidade do Tribunal. No julgamento da Rcl 1.987/DF, em que se discutiu o cabimento de reclamação

109 JR. DIDIER, Fredie. Transformações do recurso extraordinário. In: WAMBIER, Teresa Arruda; JR. NERY, Nelson. Aspectos Polêmicos e Atuais dos Recursos Cíveis e Assuntos Afins, vol. 10, São Paulo: Revista dos Tribunais, 2006, p. 109-112.

${ }^{110} \mathrm{E}$, ainda, sustentando o efeito vinculante como decorrência automática de qualquer julgado do STF, Francisco Queiroz Bezerra Cavalcanti e Roberta Lúcia Costa Ferreira dos Santos, nos seguintes termos: "Imaginemos que o Supremo Tribunal Federal, no julgamento de um recurso extraordinário, por decisão proferida pelo Plenário, firmasse definitivamente tese jurídica a respeito de determinada matéria e que, embora a decisão já estivesse apta a autorizar o Senado Federal a editar o ato legislativo capaz de suspendê-lo do ordenamento nacional, isso não ocorrera. Nesse caso, seria possível a propositura de reclamação por aqueles jurisdicionados que estivesse recebendo decisões em sentido diametralmente oposto daquele firmado pelo Pretório Excelso em sede de controle difuso de constitucionalidade? Na medida em que, o sistema de controle difuso, quando a matéria é decidida pelo órgão máximo do Supremo Tribunal, a vinculação dos julgamentos futuros está autorizada pela jurisprudência daquela Corte, entendemos que é plenamente viável a utilização da reclamação para a consecução de seus fins. O importante, por conseguinte, tecidas essas considerações, é a conformidade do ato com o entendimento fixado pelo STF, que é o intérprete máximo do Texto Constitucional, o maior 'defensor da Constituição', nos termos outorgados pela própria Carta Constitucional, pois a garantia da supremacia dos seus pronunciamentos condiz com as exigências de efetividade do processo, de realização da justiça e mesmo de resguardo da integridade do ordenamento jurídico". CAVALCANTI, Francisco de Queiroz Bezerra; SANTOS, Roberta Lúcia Costa Ferreira dos. apud MELLO, Patrícia Perrone Campos. Op. cit., p. 95-96

${ }^{111}$ MELLO, Patrícia Perrone Campos. Op. cit., p. 163-164 
contra decisões judiciais que aplicassem normas de idêntico teor à norma já declarada inconstitucional em controle concentrado-principal, o Ministro Marco Aurélio demonstrou o seu receio nesse sentido:

\begin{abstract}
"Podemos avançar para admitir, de forma linear, a apresentação, a formalização de reclamação, tendo em conta que a Corte fulminou um ato normativo? O que haverá, por exemplo, no campo tributário, se fulminada uma norma tributária, mesmo assim se partisse para a aplicação dessa norma? Admitiremos reclamações dos contribuintes em geral? Como ficará, tendo em conta os inúmeros processos que surgirão sob essa nomenclatura 'reclamação'? (...) Não sei onde vamos parar em termos de inviabilização do próprio Supremo Tribunal Federal." 112
\end{abstract}

Ora, de se imaginar que a preocupação seja muito maior caso sejam admitidas reclamações a partir de precedentes em controle difusoincidental. Aliás, o uso indiscriminado da reclamação seria mesmo um contrassenso, já que um dos fundamentos da aproximação dos dois modelos de controle e da teoria da abstrativização é a racionalização da jurisdição. Inútil seria se a reclamação simplesmente substituísse, em volume, os recursos extraordinários.

Assim, não obstante se reconheça os efeitos generalizantes conferidos por diversos instrumentos às decisões do STF em incidentes de inconstitucionalidade, a regra não tem sido, ainda, a de que o Tribunal atribua, às mesmas, força vinculante equiparável à de suas decisões em ações diretas.

No entanto, forçoso reconhecer que, caso se consolide eventual equiparação de efeitos dos dois modelos de controle no ordenamento jurídico, o alargamento do instituto da reclamação será uma consequência inevitável. Por isso, inclusive, a importância de que fosse concluído o julgamento da Rcl 4.335/AC. Caso admitida - ainda que não provida -, configuraria relevante precedente acerca do tema.

${ }^{112}$ STF, DJ, 21 maio 2004, Rcl. 1.987-DF, rel. Min. Maurício Corrêa. 


\subsection{Impactos sobre a coisa julgada}

$\mathrm{O}$ art. 485, V, CPC trata da hipótese de cabimento de ação rescisória quando a decisão transitada em julgado houver violado literal disposição de lei. É entendimento tranquilo, na doutrina e na jurisprudência, que a lei a que se refere o dispositivo abrange, também, a Constituição. Por conseguinte, vem-se admitindo o cabimento de ação rescisória (desde que proposta no prazo decadencial de dois anos) se, posteriormente, a norma na qual se assentou a decisão for declarada inconstitucional pelo STF. Ou, o contrário: se a premissa do julgado houver sido a inconstitucionalidade da norma e a mesma vier a ser considerada legítima pelo Supremo.

O problema que se coloca, sob a perspectiva da aproximação dos dois modelos de controle e da teoria da abstrativização, é se seria ou não legítimo, ao autor da rescisória, invocar precedente do STF em controle difuso-incidental.

$\mathrm{O}$ entendimento ainda dominante é o de que somente seriam invocáveis decisões proferidas em ações diretas, as quais possuem efeitos ex tunc e erga omnes automáticos. Para grande parcela da doutrina, em controle difuso-incidental, nem mesmo sendo a norma suspensa pelo Senado, a decisão poderia fundamentar a rescisória. Isto porque, os efeitos gerais conferidos pela resolução senatorial são, segundo posição majoritária, ex nunc, de modo que as situações já constituídas sob o império da lei suspensa não seriam atingidas. ${ }^{113} 114$

\footnotetext{
${ }^{113}$ É o entendimento do atual Ministro do Supremo Tribunal Federal, Luiz Fux, a quem os efeitos ex tunc da inconstitucionalidade são condição para que se possa desconstituir coisa julgada formada sob o império da lei. Confira-se: "Questão lindeira à violação literal de lei é a que pertine à declaração de inconstitucionalidade da lei aplicada, e que exsurge no prazo da propositura da ação rescisória. Tratando-se de controle concentrado e dispondo o Supremo Tribunal Federal no acórdão declaratório dos efeitos ex tunc da declaração, é imperioso o acolhimento do iudicium rescindens. Ao revés, se a declaração é oriunda de controle difuso, prestigia-se a coisa julgada e a segurança jurídica, interditando-se a ação rescisória sob os mesmos fundamentos da Súmula $\mathrm{n}^{\circ}$. 343, vale dizer: à época da decisão, o juízo não violou a lei, porquanto hígida no sistema jurídico." Cf. FUX, Luiz. Curso de direito processual civil, vol I, $3^{\mathrm{a}}$ ed., Rio de Janeiro: Forense, 2005, p. 850

${ }^{114}$ Ressalte-se, no entanto, que há autores que entendem ser ex tunc os efeitos da resolução senatorial, porquanto entendimento contrário seria incompatível com a teoria da nulidade da norma
} 
Mas, diante da crescente aproximação do controle difuso-incidental ao controle concentrado-principal e da defesa empreendida por alguns pela sua equiparação, essa concepção tradicional do art. 485, V, CPC pode ser transformada. Se não mais se fizer diferença entre a declaração de inconstitucionalidade proferida em um caso concreto daquela proferida em ação direta, ambas as decisões seriam aptas a embasar a ação rescisória. E já existem julgados nesse sentido. Confira-se:

\begin{abstract}
"PROCESSUAL CIVIL. AÇÃO RESCISÓRIA (CPC, ART. 485, V). MATÉRIA CONSTITUCIONAL. INAPLICABILIDADE DA SÚMULA 343/STF. EXISTÊNCIA DE PRONUNCIAMENTO DO STF, EM CONTROLE DIFUSO, EM SENTIDO CONTRÁRIO AO DA SENTENÇA RESCINDENDA.

(...)

7. Assim sendo, concorre decisivamente para um tratamento diferenciado do que seja "literal violação" a existência de precedente do STF, guardião da Constituição. Ele é que justifica, nas ações rescisórias, a substituição do parâmetro negativo da Súmula 343 por um parâmetro positivo, segundo o qual há violação à Constituição na sentença que, em matéria constitucional é contrária a pronunciamento do STF. Precedente da $1^{\text {a }}$ Seção: EREsp 391594/DF, Min. José Delgado, DJ de 30.05.2005.

8. No caso dos autos, a existência de precedente do STF, ainda que em controle difuso (RE 150.755-1-PE, relatado pelo Ministro Sepúlveda Pertence), reconhecendo a constitucionalidade do art. 28 da Lei 7.738, de 09.03.89, relativamente às empresas 'exclusivamente prestadoras de serviços', que anteriormente não foi aplicado sob alegação de inconstitucionalidade, enseja o cabimento da ação rescisória.

9. Embargos de divergência providos." 115
\end{abstract}

Semelhantes são, também, as discussões em torno do art. 475-L, II e $\S^{\circ}, \mathrm{CPC}^{116}$ e do art. 741 , II e parágrafo único do CPC. ${ }^{117}$ Com redação conferida pela Lei 11.232/2005, esses dispositivos consideraram inexigível o título judicial baseado em lei ou ato normativo posteriormente declarado

\footnotetext{
inconstitucional. Para estes, a suspensão da norma pelo Senado teria o condão de enquadrar a decisão do STF na hipótese do art. 485, V, CPC.

${ }^{115}$ STF, DJU, 28 maio 2007, EREsp n. 608.122/RJ, rel. Min. Teori Albino Zavascki

${ }^{116}$ CPC, art. 475-L: "A impugnação somente poderá versar sobre: II - inexigibilidade do título; $\S 1^{\circ}$ Para efeito do disposto no inciso II do caput deste artigo, considera-se também inexigível o título judicial fundado em lei ou ato normativo declarados inconstitucionais pelo Supremo Tribunal Federal, ou fundado em aplicação ou interpretação da lei ou ato normativo tidas pelo Supremo Tribunal Federal como incompatíveis com a Constituição Federal."

${ }^{117}$ CPC, art. 741: "Na execução contra a Fazenda Pública, os embargos só poderão versar sobre: II - inexigibilidade do título; Parágrafo único. Para efeito do disposto no inciso II do caput deste artigo, considera-se também inexigível o título judicial fundado em lei ou ato normativo declarados inconstitucionais pelo Supremo Tribunal Federal, ou fundado em aplicação ou interpretação da lei ou ato normativo tidas pelo Supremo Tribunal Federal como incompatíveis com a Constituição Federal."
} 
inconstitucional pelo STF, ou fundado em aplicação ou interpretação tida pela Corte como incompatível com a Constituição. ${ }^{118}$

Ocorre que os dispositivos em comento não fizeram qualquer distinção quanto à via em que declarada a inconstitucionalidade pelo Supremo. Por isso, a interpretação que parte da doutrina e da jurisprudência tem dado à sua redação é a de que englobaria, também, os precedentes emanados em controle difuso-incidental, o que denotaria uma expansão de seus efeitos para além do caso concreto.

Todavia, assim como na rescisória, ainda é majoritária a tese de que a decisão paradigma precisa ter sido proferida em ação direta, ou, ao menos, que a norma invocada tenha sido suspensa por resolução senatorial (para aqueles que entendem que a suspensão possui efeitos ex tunc).

Contudo, diante da tendência a se aproximar os efeitos do controle difuso-incidental aos do controle concentrado-principal e do desenvolvimento da teoria da abstrativização, tem sido crescente, ao menos na doutrina, entendimento diverso. A eficácia retroativa da declaração incidental passaria a ser produzida não somente entre as partes, mas também em relação a outros processos que tenham aplicado a mesma norma, possibilitando a desconstituição da coisa julgada em todos eles.

Colham-se, nesse sentido, as palavras de Leonardo Carneiro da Cunha, ao comentar o parágrafo único do art. 741, CPC:

"É importante ressaltar que, mesmo as decisões proferidas em controle difuso servem como paradigma para a aplicação do mencionado dispositivo, tendo em vista a eficácia ultra partes e paradigmática que vem sendo dada pelo STF a tais decisões, em fenômeno que já se designou de 'objetivação' do controle difuso de constitucionalidade. Para a aplicação do dispositivo é desnecessária a resolução do Senado $(\mathrm{CF} / 88$, art. 52, X), suspendendo a vigência da lei." 119

\footnotetext{
118 Não se adentrará aqui na discussão acerca da constitucionalidade ou não dos referidos dispositivos, tendo em vista terem criado nova hipótese de relativização da coisa julgada.

119 CUNHA, Leonardo Carneiro da. A Fazenda Pública em juízo. 10 a ed. São Paulo: Dialética, 2012, p. 310. Nesse mesmo sentido, citado por Leonardo Carneiro da Cunha, Teori Albino Zavascki: "É indiferente, também, que o precedente tenha sido tomado em controle concentrado ou difuso ou que, neste último caso, haja resolução do Senado suspendendo a execução da norma. Também essa distinção não está contemplada no texto normativo, sendo de anotar que, de qualquer sorte, não seria cabível resolução do Senado na declaração de inconstitucionalidade parcial e na que decorre a interpretação conforme a Constituição. Além de não prevista na lei, a distinção restritiva não é compatível com a evidente intenção do legislador, já referida, de
} 
Essa interpretação, caso venha a se refletir na jurisprudência, produzirá efeitos imediatos sobre a relativização da coisa julgada inconstitucional. Se, hoje, as hipóteses de invocação do $\S 1^{\circ}$ do art. 475 e do parágrafo único do art. 741, CPC já não são raras, muito mais frequentes se tornariam diante desse novo e eventual panorama. Os precedentes da Corte em controle difuso-incidental são, deveras, mais comuns do que em sede concentrada, bem como superam, em muito, o número de resoluções senatoriais suspensivas.

Outro ponto relativo ao impacto da teoria da abstrativização sobre a res iudicata merece destaque, especialmente, em razão de recente parecer jurídico da Procuradoria Geral da Fazenda Nacional (PGFN/CRJ/N. 492/2011). ${ }^{120}$ Refere-se à coisa julgada nas relações de trato sucessivo.

Em suma, quando transita em julgado decisão acerca de uma relação jurídica continuada, os efeitos vinculantes da coisa julgada abrangem os fatos supervenientes subjacentes àquela relação se e enquanto durarem os suportes fáticos e jurídicos que embasaram a referida decisão (art. 471, I, $\left.\mathrm{CPC}^{121}\right)$. Alterados estes, é como se nascesse uma nova relação jurídica, não abrangida pelos efeitos vinculantes da coisa julgada (limites objetivos).

Nesse contexto, pode ser que a sentença sob a proteção da res iudicata tenha tido como pressuposto lógico a constitucionalidade ou inconstitucionalidade de uma norma. E se, posteriormente, essa mesma norma vier a ser interpretada em sentido contrário pelo Supremo? Daí, então, terá havido mudança no suporte jurídico da decisão transitada em julgado. Nos termos do que foi dito acima, a parte beneficiada com essa alteração poderá requerer a revisão do julgado.

valorizar a autoridade dos precedentes emanados do órgão judiciário guardião da Constituição, que não pode ser hierarquizada em função do procedimento em que se manifesta".

${ }^{120}$ MACEDO, Laura Vargas. Op. cit.

${ }^{121} \mathrm{CPC}$, Art. 471: "Nenhum juiz decidirá novamente as questões já decididas, relativas à mesma lide, salvo: I - se tratando de relação jurídica continuativa, sobreveio modificação no estado de fato ou de direito; caso em que poderá a parte pedir a revisão do que foi estatuído na sentença." 
O ponto que se coloca, uma vez mais, é: a decisão do STF, proferida em um caso concreto, é capaz de ensejar a revisão de todos os julgados que tenham aplicado a norma em questão?

Segundo o aludido parecer da PGFN, aprovado pelo Ministro de Estado da Fazenda, a resposta é positiva. Após discorrer sobre a dessubjetivação do controle difuso-incidental, a Procuradora da Fazenda Laura Vargas Macedo concluiu:

\begin{abstract}
"Assim, as razões expostas ao longo deste tópico indicam que, por serem objetivos e definitivos, possuem força para, com o seu advento, impactar ou alterar o sistema jurídico vigente, os seguintes precedentes do STF: (i) todos os formados em controle concentrado de constitucionalidade, independentemente da época em que prolatados; (ii) quando posteriores a 3 de maio de 2007, aqueles formados em sede de controle difuso de constitucionalidade, seguidos, ou não, de Resolução Senatorial, desde que, nesse último caso, tenham resultado de julgamento realizado nos moldes do art. 543-B do CPC; (iii) quando anteriores a 3 de maio de 2007, aqueles formados em sede de controle difuso de constitucionalidade, seguidos, ou não, de Resolução Senatorial, desde que, nesse último caso, tenham sido oriundos do Plenário do STF e sejam confirmados em julgados posteriores da Suprema Corte."122
\end{abstract}

E mais: segundo consta da peça opinativa, sequer seria necessário pronunciamento judicial para fazer cessar os efeitos vinculantes da decisão transitada em julgado. Isso se operaria automaticamente, "como mera e natural decorrência lógica do que se entende por limites objetivos da coisa julgada", já que se estaria diante de nova relação jurídica. Vê-se que o órgão fazendário opinou, ainda que com algumas ressalvas ${ }^{123}$, pela consolidação da teoria da abstrativização, equiparando os efeitos das

\footnotetext{
122 A ilustre Procuradora considera a sistemática de julgamento dos recursos repetitivos, introduzida no art. 543-B, CPC, um marco na aproximação dos efeitos do controle difusoincidental aos do controle concentrado-principal, porque teria ocasionado um verdadeiro desprendimento do julgamento em relação ao caso concreto e às suas vicissitudes. Assim, um só julgado através desse novo regramento já teria definitividade e objetividade suficientes para "alterar ou impactar o sistema jurídico vigente, agregando-lhe um novo elemento." Por isso a distinção entre julgados anteriores e posteriores a 3 de maio de 2007, quando a sistemática passou a integrar o Regimento Interno do STF e a ser utilizada. Mas, mesmo em relação às decisões anteriores a essa data, a parecerista entende ser possível falar em objetividade e definitividade, desde que a decisão tenha sido proferida pelo plenário da Corte e desde que o entendimento tenha se repetido em outros julgados.

${ }^{123}$ Com algumas ressalvas porque a PGFN sustentou a produção de efeitos erga omnes e vinculantes automáticos não a qualquer decisão incidental do STF, mas apenas em relação àquelas proferidas sob a sistemática dos recursos repetitivos ou, se anteriores à introdução do instituto, acaso confirmadas por posteriores decisões da Corte.
} 
decisões do STF em controle difuso-incidental aos das decisões proferidas em ações diretas.

Ora, o impacto dessa conclusão é imenso. Imagine-se que diversas relações tributárias foram consideradas inexistentes em razão da inconstitucionalidade da lei instituidora do tributo. As decisões transitam em julgado e os supostos contribuintes se livram do pagamento do tributo. Posteriormente, essa lei é declarada constitucional pelo STF em uma outra relação tributária levada a juízo, julgada sob a sistemática dos recursos repetitivos. Segundo o entendimento veiculado no parecer da PGFN, a partir dessa decisão, automaticamente, o Fisco poderá cobrar o tributo de todos aqueles que estavam protegidos pelo manto da coisa julgada.

É de se ver, portanto, que, a defesa não só da aproximação como de uma efetiva equiparação entre os efeitos dos dois modelos de controle já faz parte do discurso de alguns daqueles que operam com o Direito. E o instituto da coisa julgada seria mais um a sofrer as consequências desse fenômeno. 


\section{Capítulo 4 \\ Críticas}

\subsection{Limitações processuais}

A aproximação do controle difuso-incidental ao controle concentrado-principal, bem como a pretensão de equipará-los, não são aceitas de forma pacífica na doutrina e na jurisprudência. Pelo contrário, o tema é motivo de intensos debates e alguns autores não poupam críticas a sua efetivação.

Sobretudo no que toca à pretensão de se consolidar a teoria da abstrativização, uma das dificuldades apontadas pelos críticos são as limitações processuais a eventual equiparação dos dois modelos de controle. É que, como já acentuado, o nosso sistema processual veda, expressamente, a imutabilidade de questões prejudiciais decididas incidentalmente no processo até mesmo para as partes (art. 469, III, $\mathrm{CPC}^{124}$ ), salvo na hipótese do art. 470, CPC. ${ }^{125}$ Assim, esse regramento constituiria óbice à atribuição automática de efeitos vinculantes e erga omnes à decisão do incidente de inconstitucionalidade. Isto porque, estarse-ia produzindo uma imutabilidade da decisão incidental não só para as partes - o que por si só é vedado - como para terceiros.

Sob esse argumento, Alfredo Buzaid criticou a teoria da abstrativização ainda nos seus primórdios, quando sustentada por pouquíssimos adeptos, como Lúcio Bittencourt e Castro Nunes. Confira-se

\footnotetext{
${ }^{124}$ CPC, art. 469: "Não fazem coisa julgada: III - a apreciação da questão prejudicial, decidida incidentemente no processo."

${ }^{125} \mathrm{CPC}$, art. 470: "Faz, todavia, coisa julgada a resolução da questão prejudicial, se a parte o requerer (artigos $5^{\circ}$ e 325 ), o juiz for competente em razão da matéria e constituir pressuposto necessário para o julgamento da lide." $\mathrm{O}$ art. $5^{\circ}$, por sua vez, exige que a questão prejudicial a que se queira conferir os efeitos da coisa julgada, através da ação incidental, refira-se à existência ou não de uma relação jurídica.
} 
“...teriam razão os ilustres autores (referindo-se a Lúcio Bittencourt e Castro Nunes) se, no litígio constitucional, o objeto do processo fosse a lei em si, não o direito subjetivo da parte; nestas condições, a coisa julgada, transcendendo os limites da demanda, abrangeria a todos. Mas enquanto os juízes resolvem in casu o direito particular, ameaçado ou violado por ato ilegal da legislatura ou do executivo, os efeitos do julgado valem inter partes, não se estendendo erga omnes." $" 126$

Por sua vez, aqueles que apoiam a teoria da abstrativização argumentam que obstaculizá-la por um mero fator formal, seria se contrapor à realidade jurídica atual, criando uma distinção artificial entre os dois modelos de controle. Distinção esta que residiria, meramente, em razão de índole ontológica. ${ }^{127}$

Esse o ponto de vista expressado por Dirley da Cunha Júnior, in verbis:

"De fato, se no passado se tolerava a distinção, hodiernamente, ela é intolerável, diante da posição de Guardião da Constituição da qual se reveste a Corte. Ora, no contexto atual, é absolutamente sem sentido, chegando a soar como teratológica a explicação de que, no controle difuso, o Supremo decide inter partes, enquanto que no controle concentrado decide erga omnes. Tudo isso só porque o STF, na primeira hipótese, declara a inconstitucionalidade resolvendo uma questão incidental, e, na segunda, declara a mesma inconstitucionalidade solucionando a própria questão principal. Onde está a lógica disso, já que - seja decidindo incidenter tantum ou principaliter tantum - o órgão prolator da decisão é o mesmo?"128

Mas, o fato é que se trata de uma concepção enraizada em nosso ordenamento jurídico, a sustentar toda uma lógica processual. Difícil, por isso, a sua superação. Logo, não há dúvidas: está-se diante de um dos empecilhos à ideia de total equiparação entre os efeitos dos dois modelos de controle.

\footnotetext{
${ }^{126}$ BUZAID, Alfredo apud LENZA, Pedro. Op. cit., 188

${ }^{127}$ MACEDO, Laura Vargas. Op. Cit. p. 217

${ }^{128}$ CUNHA JR., Dirley da. apud MACEDO, Laura Vargas. Op. cit., p. 216
} 


\subsection{Concentração de poderes no STF, engessamento do direito e ameaça à democracia}

Crítica severa dirigida à aproximação dos dois modelos de controle e, consequentemente, à teoria da abstrativização reside na concentração de poderes nas mãos do STF - propiciada pelo fenômeno - e as consequências disso advindas.

Para muitos autores, a paulatina eficácia impositiva que se vem conferindo às decisões da Corte, em detrimento do poder decisório das demais instâncias, abre espaço para o arbítrio, na medida em que toda a concentração de poder proporciona arbitrariedades. Além disso, eventual consolidação da teoria da abstrativização, conferindo-se eficácia geral e vinculante automática às decisões do STF em controle difuso-incidental, aos poucos, aniquilaria a independência funcional dos magistrados, "amordaçando-os". Isso já estaria ocorrendo, segundo alguns juristas, pela tão só aproximação entre os dois modelos de controle.

Nesse sentido, Lênio Luiz Streck, um dos principais críticos dos mecanismos atribuidores de eficácia erga omnes às decisões do Supremo, expôs a sua preocupação ao comentar o instituto da súmula vinculante.

Citando o conselheiro da OAB, Reginaldo Castro, pronunciou-se o célebre doutrinador:

"CASTRO, chama a atenção para o fato de que, 'criada a Súmula, as decisões do STF teriam efeito erga omnes. Nenhum outro tribunal ou juiz poderia contestálas. Imagine-se como isso funcionaria num contexto de exceção política: um Presidente da República menos escrupuloso poderá, pelo menos em tese, iludindo a boa-fé do tribunal, provocar a constituição de súmula vinculante que interesse a seus propósitos e, com ela, amordaçar 'legalmente' a sociedade e a própria estrutura do Judiciário'. Não se trata aí, continua o autor, de duvidar da integridade moral do STF ou de seus integrantes. Isso não está em jogo. O que ocorre é que o autoritarismo, quando se estabelece, 'fere de morte a autonomia dos poderes'. E a reação é inexoravelmente lenta e penosa, em face da complexidade do processo político." 129

\footnotetext{
${ }^{129}$ STRECK, Lênio Luiz. O fahrenheit sumular do Brasil: o controle panóptico da justiça. Op. cit., p. 8
} 
Não fosse o bastante, a vinculação erga omnes, através da súmula vinculante, às decisões da Suprema Corte acerca da constitucionalidade de uma norma viria transformando-a em verdadeiro legislador positivo. A sua palavra passaria a, sempre, valer mais do que a lei. Isso abalaria, sobremaneira, a harmonia entre os Poderes da República. ${ }^{130}$

Somado a isso, Lênio Luiz Streck, ainda analisando a (então) novidade da súmula vinculante, previu outros dois efeitos indesejáveis da eficácia normativa atribuída às decisões do STF em sede de controle difusoincidental. São eles: (i) no plano político, a provável consolidação de posições mais conservadoras, marginalizando diversos setores da sociedade e (ii) no plano hermenêutico, o engessamento do direito, obstando o aparecer das singularidades do caso concreto. ${ }^{131}$

Sob essa ótica, mais grave ainda do que o verbete sumular seria, por óbvio, a atribuição automática de efeitos erga omnes e vinculantes às decisões proferidas na via incidental, porquanto se sacramentaria a posição do STF como intérprete único da Constituição. Em última análise, isso seria conferir-lhe um poder não desejado pelo constituinte. Isto porque, se, por um lado, a Lei Maior atribuiu, ao órgão de cúpula do Judiciário, a competência de sobre ela dar a última palavra, por outro, isto não significa que lhe foi conferido o monopólio da interpretação constitucional. Pelo contrário, a manutenção do controle difuso-incidental exerceria, justamente, o importante papel de democratizar a interpretação da Constituição. ${ }^{132}$

A possibilidade de que, difusamente, todas as instâncias judiciárias também participem do processo de interpretação do texto constitucional evitaria a consolidação de posições exclusivamente conservadoras e abriria espaço para divergências, tão importantes no processo hermenêutico. ${ }^{133} \mathrm{E}$ isso seria especialmente relevante considerando-se o histórico brasileiro.

\footnotetext{
${ }^{130}$ Ibid. p. 4-5

${ }^{131}$ Ibid. p. 10

${ }^{132}$ LEITE, Fábio Carvalho. Op. Cit. p. 15-16

${ }^{133}$ Ibid. p. 16
} 
Não se poderia menosprezar a convivência de diversos grupos étnicos, sociais, políticos e econômicos no seio de nossa sociedade. ${ }^{134}$

Nesse contexto, somente os juízes das instâncias ordinárias conheceriam as peculiaridades dos casos concretos, apenas eles acompanhariam os dramas a estes subjacentes. ${ }^{135}$ Por conseguinte, a eles seria imprescindível deter o poder de analisar, livremente, a questão constitucional enquanto questão prejudicial à solução do caso lhes posto a exame.

Assim, enquanto o controle concentrado-principal serviria, especificamente, para manter a higidez do ordenamento jurídico objetivo, o controle difuso-incidental se prestaria a aproximar a jurisdição constitucional da sociedade. ${ }^{136}$

Anotem-se, sob esse prisma, as palavras de Álvaro Ricardo de Souza Cruz:

\begin{abstract}
"O controle difuso aproxima a Jurisdição Constitucional e a sociedade. Disperso por todos os ramos do Judiciário, especialmente nas comarcas da Justiça Estadual ordinária, o controle difuso tem o condão de incrementar o exercício da cidadania, robustecendo a noção de democracia, especialmente em países como o Brasil, com uma história constitucional tão atribulada. Assim, não somente os tribunais, normalmente distantes, situados em capitais dos Estados ou da República, que têm atribuição exclusiva para apreciação da constitucionalidade de leis e debates sobre a aplicação de leis e de atos normativos. Além disso, qualquer indivíduo tem legitimidade para argüí-la desde que o faça no bojo de processo que discuta concretamente ameaça/violação de direito subjetivo, seja ele individual, heterogêneo ou homogêneo, coletivo ou difuso."137
\end{abstract}

Portanto, não à toa o constituinte teria optado pela manutenção desse modelo ao lado do controle concentrado-principal. Fê-lo como forma de impedir a supremacia incontestável da posição do STF e, assim, fortalecer a democracia.

\footnotetext{
${ }^{134}$ MORAIS, Dalton Santos. Crítica à caracterização da atuação senatorial no controle concreto de constitucionalidade brasileiro como função de publicidade. p. 2. Revista JusNavigandi. Disponível em <http://www.jus.com.br>. Acesso em 23 de julho de 2012.

135 Ibid.

136 Ibid.

${ }^{137}$ CRUZ, Álvaro Ricardo de Souza apud MORAIS, Dalton Santos. Ibid.
} 
Veja-se, também, nesse diapasão, o juízo de Fábio Carvalho Leite acerca do desejo, de parte da comunidade jurídica, de equiparar o controle difuso-incidental ao controle concentrado-principal:

\begin{abstract}
"A ideia de que o Brasil caminha para uma concentração no controle de constitucionalidade, ou mais precisamente a forma como esta ideia tem se propagado, desacompanhada de um debate sério, profundo e honesto, revela-se no mínimo preocupante, em razão de pelo menos uma importante consequência que tem sido ocultada ou que ao menos não tem sido discutida de forma clara: a centralização da interpretação do texto constitucional - ou, colocado em termos talvez mais dramáticos, mas não menos verdadeiros, a exclusão de diversos setores da sociedade (incluindo os demais órgãos do Poder Judiciário) do processo de interpretação da Constituição. A ausência de um debate sobre este ponto - sonegado em meio à campanha pela centralização do controle de constitucionalidade - dificulta se não mesmo impede que se identifique uma legitimidade na proposta, que, aliás, parece conquistar espaço apenas quando resulta de procedimentos exclusivos do STF, ou seja, em sua própria jurisprudência e no seu regimento interno." 138
\end{abstract}

Ainda advertindo para os perigos de eventual consolidação da teoria da abstrativização, Lênio Luiz Streck - desta vez junto a Marcelo Andrada Cattoni de Oliveira e Martonio Mont'Alverne Barreto Lima - conjuga o poder que seria conferido ao STF, por meio da equiparação entre os dois modelos de controle, aos institutos da repercussão geral e da sistemática de julgamento de recursos repetitivos, in verbis:

\begin{abstract}
"Observe-se a complexidade do problema: além do poder que o Supremo Tribunal Federal terá a partir da equiparação do controle difuso ao controle concentrado, tem-se que aquela Corte pode, agora, determinar a interpretação de uma norma constitucional e impô-la a todos os processos em sede de controle difuso. Podem ser anuladas, inclusive, decisões já proferidas pelas diversas instâncias do Poder Judiciário. Portanto, como bem alerta Fernando Faccury Scaff, isto é mais do que uma súmula vinculante: é uma decisão única, tomada por seis ministros (maioria absoluta), que pode desfazer decisões adotadas pelos Tribunais de todo o País. A exigência de quórum qualificado (oito votos) é apenas para o juízo de admissibilidade e não para a votação do mérito. É um poder jamais visto no Brasil nas mãos do STF."139
\end{abstract}

E é analisando todos esses aspectos que o autor afirma que, se o objetivo da tendência à aproximação dos dois modelos de controle, bem

\footnotetext{
${ }^{138}$ LEITE, Fábio Carvalho. Op. cit. 15

139 STRECK, Lênio Luiz et. al. A Nova Perspectiva do Supremo Tribunal Federal sobre o Controle Difuso: Mutação constitucional e Limites da Legitimidade da Jurisdição Constitucional. Op. cit. p. 4
} 
como da pretensão de equipará-los, é a racionalização da jurisdição, então estaríamos pagando um preço muito caro pela contrapartida. Conferir efeitos generalizantes - e ainda que não de modo automático - às decisões do órgão de cúpula do Judiciário seria buscar uma solução simplista para um problema complexo.

Nessa linha, mais uma vez, as palavras do respeitável autor:

\begin{abstract}
"Não tenho medo de afirmar que trocar a democracia e a independência dos juízes pelo desafogo dos processos - tese que começa perigosamente a ser aceita até mesmo pelos que são contrários à vinculação sumular - me parece um preço exageradamente alto a ser pago por todos nós. Ou seja, ao acreditarem na simplista tese de que o desafogo do aparelho judiciário depende de providência drásticas do quilate das súmulas vinculantes, súmulas impeditivas de recurso, efeito vinculante em ação declaratória de constitucionalidade, em decisão que rejeita ação direta de inconstitucionalidade, em decisão que aplica a interpretação conforme a Constituição e a nulidade parcial sem redução de texto, além dos mecanismos de filtragem recursal constantes na Lei 9.756/98, os operadores do Direito agem como aquele sujeito que perdeu o relógio em uma praça escura e põe-se a procurá-lo, longe dali, debaixo de uma luminária. Perguntado acerca de sua conduta, destituída de qualquer racionalidade, o sujeito responde: - Ora, aqui é bem mais fácil procurar...!"140 141
\end{abstract}

Por outro lado, cabe destacar registro feito por Luís Roberto Barroso, ao comentar as críticas dirigidas à força geral e vinculante atribuída aos precedentes do STF de um modo geral. O apontamento, sem dúvidas, se aplica às decisões da Corte proferidas no exercício do controle difusoincidental de leis e atos normativos, pertinente ao presente estudo. $\mathrm{O}$ ilustre doutrinador sustenta que, dessa força normativa dos precedentes, deve-se extrair uma vinculação apenas prima facie, que pode não prevalecer diante de peculiaridades do caso concreto. Nessas circunstâncias, não se trataria de mera divergência doutrinária do magistrado e sim da constatação de que a tese jurídica firmada pela Suprema Corte não realiza a justiça do caso

140 STRECK, Lênio Luiz. O fahrenheit sumular do Brasil: o controle panóptico da justiça. Op. cit., p. 7-8.

${ }^{141} \mathrm{O}$ autor propõe, como solução para o desafogo do Judiciário, a utilização de outras técnicas, tais como: o exame mais detalhado pelos juízos ordinários dos requisitos das petições iniciais, evitando-se a formação de inúmeros processos; o uso mais adequado do despacho saneador; a criação de tribunais administrativos para a resolução de controvérsias administrativas e fiscais; a expansão no número de comarcas, juízes e ministros do STJ e do STF; a imediata remessa das decisões em controle difuso-incidental ao Senado, para que este, também de imediato, emita a resolução suspensiva da lei, entre outras. Ibid. p. 13-15. 
concreto que lhe cabe decidir. Isto seria viável, na medida em que o próprio STF já afirmou que uma norma pode ser constitucional em abstrato, mas inconstitucional em concreto. Naturalmente, potencializa-se, nessa hipótese, o ônus argumentativo do prolator do decisum. ${ }^{142}$

Essa compreensão, segundo o autor, rebateria as objeções feitas à valorização dos precedentes da mais Alta Corte do país. Adotando-se essa lógica, não haveria risco de se violar a consciência do juiz e nem tampouco perigo de engessamento do direito.

Semelhante linha de entendimento demonstrou André Ramos Tavares, em artigo favorável à súmula vinculante, mas cujos comentários servem, em alguma medida, à tendência de aproximação dos dois modelos de controle, bem como à pretensão de equipará-los. Observe-se:

\begin{abstract}
"Como sustentar que na livre convicção do magistrado (que é essencial à própria sobrevivência do sistema, e só por isso existe como princípio) esteja contida a liberdade arbitrária do magistrado, a discordar dos posicionamentos já amplamente fixados sobre o Direito posto (e que conduziriam à derrocada do próprio sistema jurídico)? (...). Há riscos, é claro. Mas igualmente não há como deixar de assumí-los, na busca de um sistema que se baseie menos na sorte (loteria de pensamentos jurídico-judiciais divergentes em relação a temas largamente debatidos) e mais na previsibilidade, própria da finalidade que se atribui ao e que justifica o Direito." 143
\end{abstract}

É certo que, acaso consolidada a efetiva equiparação do controle difuso-incidental ao controle concentrado-principal, tais argumentos não serviriam para os casos de declaração de inconstitucionalidade de uma norma. Isto porque a consequência da pronúncia de inconstitucionalidade seria a imediata extirpação da disposição normativa do ordenamento jurídico. Deste modo, impedida estaria uma reavaliação dos demais magistrados diante do caso concreto. Mas, para todas as outras possíveis decisões da Suprema Corte em um incidente de inconstitucionalidade, a invocação do raciocínio exposto seria, ao menos, defensável.

\footnotetext{
${ }^{142}$ BARROSO, Luís Roberto, no prefácio do livro de Patrícia Perrone. MELLO, Patrícia Perrone Campos. Op. cit.

${ }^{143}$ TAVARES, André Ramos. Perplexidades do Novo Instituto da Súmula Vinculante no Direito Brasileiro. Op. cit. p. 12
} 
Sem embargo, a questão é que as críticas aqui narradas são apontamentos sérios da doutrina em oposição à atribuição de efeitos generalizantes às decisões proferidas pelo STF em controle difusoincidental. Assim, sobretudo quando se sustenta a teoria da abstrativização, pela qual a produção de tais efeitos se daria de modo automático, há que se levar em consideração os argumentos aqui levantados. Eles certamente merecem profunda reflexão sobre o tema.

\subsection{Agravamento da dificuldade contramajoritária}

É cediço que, ao declarar inconstitucional um ato do Legislativo ou de um membro eleito do Executivo, o Poder Judiciário exerce uma função política, em oposição à vontade de representantes do povo. Opõe-se, em última análise, e ainda que idealmente, aos desejos da maioria. Esse fenômeno é denominado, pela doutrina, de dificuldade contramajoritária.

Mas, sabe-se, também, que diversos argumentos foram elaborados, pela teoria constitucional, de modo a justificar a legitimidade do Judiciário para sobrepor as suas decisões às dos agentes públicos eleitos.

Talvez a principal razão para esse poder conferido à jurisdição constitucional seja a percepção, pelo próprio constituinte originário, de que "a democracia não se esgota na afirmação simplista da vontade majoritária." ${ }^{144}$ Ao contrário, a democracia deve ser vista como a possibilidade de participação das minorias nos rumos da sociedade, numa acepção substantiva do conceito. O constituinte teria querido resguardar consensos mínimos essenciais, como são os direitos fundamentais, da atuação lesiva de maiorias eventuais. Assim, o fato de os membros do Judiciário não serem eleitos, seria, na verdade, um pressuposto para a sua neutralidade, uma vez que a regra da maioria nem sempre representa a democracia substancial.

${ }^{144}$ BARROSO. Luís Roberto. Curso de Direito Constitucional Contemporâneo. Op. cit., p.185 
Mas, ainda assim, à evidência de que nem sempre o argumento possa ser suficiente, a jurisdição constitucional atua numa busca constante de mecanismos aptos a reforçar a legitimidade democrática de suas decisões. A admissão de amicus curiae, por exemplo, nos julgamentos de questões constitucionais, cuja decisão afete a toda a sociedade, é um reflexo dessa orientação.

Entretanto, a questão que se coloca, quando se fala em uma possível abstrativização do controle difuso-incidental no âmbito do STF, é que a consolidação dessa teoria agravaria a dificuldade contramajoritária, ao invés de amenizá-la.

É que, conforme enfatizado no item anterior, o exercício do controle de constitucionalidade por todos os órgãos do Poder Judiciário e a possibilidade de que os cidadãos levem a juízo - e possam ter efetivamente acolhidas - as suas visões acerca do texto constitucional, democratiza a interpretação da Constituição. Dessa forma, a ampla possibilidade de divergência e do acolhimento de variados pontos de vista acerca do texto constitucional em controle difuso-incidental, contribuiria para legitimar, até mesmo, o juízo definitivo do STF sobre o tema, em eventual ação direta. Ao revés, a vinculação de todas as instâncias a um entendimento único do Tribunal, emanada diante de um processo específico e à revelia das posições de tantos outros magistrados, detonaria essa possibilidade. Com isso, conforme fossem proferidas decisões da Corte em processos subjetivos, aniquilar-se-ia, aos poucos, esse debate jurisdicional, até que só restassem as opiniões dos membros do STF a respeito da Constituição. Por conseguinte, isso resultaria em um sério agravamento da dificuldade contramajoritária. Apenas onze pessoas - ou melhor, seis, considerando-se ser exigida apenas a maioria absoluta para um juízo de constitucionalidade - deteriam, exclusivamente, o poder de rejeitar as decisões dos agentes públicos eleitos, privilegiando as suas próprias.

É certo que a própria Constituição, originalmente, já indicou para essa possibilidade. Mas o fez exigindo a chancela do Senado, o qual, como 
órgão de membros eleitos, teria, justamente, o importante papel de conferir a necessária legitimidade democrática à decisão da Suprema Corte, que passaria a não mais poder ser contestada.

Exponha-se, ainda, a crítica de que a própria ideia de observância geral e obrigatória automática de todo e qualquer juízo de constitucionalidade proferido por um órgão do Judiciário, suscita dúvidas quanto à sua legitimidade democrática para tanto. Em um país originário da civil law, que escolheu o Poder Legislativo como criador de direitos e obrigações de caráter geral e vinculante, torna-se árdua a missão de se comprovar legítima a pretensão em análise.

Note-se, nada obstante, e apenas para fazer um contraponto, que há autores que entendem em sentido oposto. A possibilidade de que qualquer cidadão suscite, principalmente através do recurso extraordinário, o controle de constitucionalidade abstrato, amplificaria a legitimidade democrática das decisões emanadas pelo STF.

É o que pensa o Procurador Federal, Eduardo Francisco de Souza, que assim anotou ao apontar as vantagens da teoria da abstrativização:

\begin{abstract}
"Invoca-se uma manifesta economia processual que a tendência pode ensejar, pois se teria, como já dito, a declaração de inconstitucionalidade de uma lei em sede de controle difuso, mas com efeito erga omnes, não sendo exigido das pessoas que se encontrem na mesma situação jurídica, que estas ingressem em juízo para que obtenham o mesmo efeito prático já obtido pelo primeiro demandante. Ademais, a tendência vai ao encontro dos anseios do moderno constitucionalismo, que pleiteia amplificação da legitimidade do debate constitucional, conforme alinhamos em passagem anterior."
\end{abstract}

Em que pese a posição do citado jurista, é inequívoco que tudo o que foi exposto quanto à legitimidade democrática, conferida pelo controle difuso-incidental às decisões da Suprema Corte, enseja dúvidas a respeito da viabilidade de eventual equiparação entre os efeitos dos dois modelos de controle.

\footnotetext{
${ }^{145}$ SOUZA, Eduardo Francisco de. A abstração do controle difuso de constitucionalidade. Op. cit., p. 9
} 


\subsection{Lesão a direitos fundamentais}

Outra crítica, não menos importante, que se faz à aproximação dos dois modelos de controle e à teoria da abstrativização, é a de que ensejariam a violação de direitos fundamentais.

O argumento, nesse sentido, é o de que a extensão, a terceiros, dos efeitos de decisão prolatada em um caso concreto específico, resultaria numa interferência em suas esferas jurídicas sem que lhes fosse oportunizado o contraditório e a ampla-defesa.

Sobre esse ponto, apropriada a transcrição de mais um trecho da obra de Lênio Luiz Streck, Marcelo Andrada Cattoni de Oliveira e Martonio Mont'Alverne Barreto Lima:

“...há também uma consequência grave para o sistema de direitos e garantias fundamentais, Dito de outro modo, atribuir eficácia erga omnes e efeito vinculante às decisões do STF em sede de controle difuso de constitucionalidade é ferir os princípios constitucionais do devido processo legal, da ampla defesa e do contraditório (art. $5^{\circ}$, LIV e LV, da Constituição da República), pois assim se pretende atingir aqueles que não tiveram garantido o seu direito constitucional de participação nos processos de tomada de decisão que os afetará. Não estamos em sede de controle concentrado (...). Eis, portanto, um problema central: a lesão a direitos fundamentais." 146

Seria como se a relação jurídica de diversos cidadãos ficasse dependente dos argumentos levado a juízo por apenas um indivíduo, que sequer possui legitimidade para representar os interesses de todos aqueles submetidos à disciplina da norma impugnada.

Eis, portanto, mais um óbice oposto por parte da doutrina à aproximação dos dois modelos de controle e a pretensão de equiparar os efeitos das decisões do STF em controle difuso-incidental aos das decisões prolatadas em ações diretas.

\footnotetext{
146 STRECK, Lênio Luiz et. al. A Nova Perspectiva do Supremo Tribunal Federal sobre o Controle Difuso: Mutação constitucional e Limites da Legitimidade da Jurisdição Constitucional. Op. cit. p. 7
} 


\title{
4.5. A existência da súmula vinculante
}

Especialmente no que toca à teoria da abstrativização, ou seja, à pretensão de se conferir efeitos erga omnes e vinculantes automáticos às decisões do STF, existe uma crítica feita, inclusive, por muitos daqueles que defendem a aproximação dos dois modelos de controle: a de que a súmula vinculante já supre os anseios dos adeptos da abstrativização.

A súmula vinculante, além de prever a produção de efeitos erga omnes ao enunciado sumular, torna a sua observância obrigatória ao Judiciário e à Administração Pública, assim como ocorre nas decisões em ações diretas. A diferença é que ela exige uma série de cautelas, evitando tornar obrigatórias teses pouco testadas e debatidas, o que acabaria ocorrendo caso esses mesmos efeitos fossem automaticamente produzidos em qualquer decisão avulsa do STF em controle difuso-incidental.

Veja-se, nessa linha, a posição esposada por Pedro Lenza:

\begin{abstract}
"Sustentamos (já que não nos filiamos à teoria da abstrativização) a possibilidade de se conseguir o objetivo pretendido mediante a edição de súmula vinculante, o que, em nosso entender, seria muito mais legítimo e eficaz, além de respeitar a segurança jurídica, evitando o casuísmo.

Lembramos que a súmula vinculante, para ser editada, deve preencher os requisitos do art. 103-A, como a exigência de reiteradas decisões sobre a matéria constitucional controvertida.

No mais, a segurança se completa com o quórum qualificado de $2 / 3$ para a edição da súmula vinculante, mais seguro, para efeitos de abstrativização, do que o quórum normal do controle difuso que é o da maioria absoluta (art. 97)."147
\end{abstract}

Nesse mesmo sentido foram os votos do Min. Sepúlveda Pertence e do Min. Joaquim Barbosa na Rcl 4.335/AC, ao refutarem a tese de mutação constitucional do art. 52, X, CRFB, levantada pelo Min. Gilmar Mendes. Conforme se extrai dos Informativos 454 e 453 do $\mathrm{STF}^{148}$, ambos os ministros asseveraram que o instituto da súmula vinculante já dotou a

\footnotetext{
147 LENZA, Pedro. O Senado é um mero menino de recado? Disponível em < http://pedrolenza.blogspot.com.br/2011/05/o-senado-federal-e-um-mero-menino-de.html>

${ }^{148}$ Disponível em <http://www.stf.jus.br>
} 
Suprema Corte do poder de conferir efeitos gerais e obrigatórios às suas decisões em controle difuso-incidental. Tal instituto seria suficiente para as pretensões "abstrativizadoras", sendo desnecessário reduzir o papel do Senado ao de um mero órgão de publicidade. E, de fato, como já assinalado, a edição da súmula vinculante $n$. 26 parece sugerir que essa foi a posição adotada pelo STF. 


\section{Conclusão}

Ao longo deste trabalho, procurou-se demonstrar o crescente movimento de aproximação dos efeitos do controle difuso-incidental aos do controle concentrado-principal e como isso fortaleceu a teoria da abstrativização, que visa à equiparação dos dois modelos de controle através da atribuição de eficácia erga omnes e vinculante automática às decisões do STF proferidas no exame de casos concretos.

Em que pese seja a tendência à aproximação dos dois modelos uma realidade - principalmente, em virtude dos diversos mecanismos conferindo força erga omnes aos precedentes do STF - a mesma não escapa das críticas de parcela da doutrina. E a equiparação é vista, hoje, com cautela ainda maior, enfrentando resistências até mesmo de alguns daqueles que concordam com a aproximação a que se vem procedendo.

É certo que a teoria da abstrativização do controle difuso-incidental já esteve presente com maior força no próprio STF, mas a atual resistência da Corte em enfrentá-la não significa que uma eventual consolidação não seja possível. Pelo contrário, ainda são intensos os debates doutrinários acerca de sua implementação. A própria Corte, por vezes, profere decisões que, indiretamente, parecem indicar que as suas decisões em controle difuso-incidental teriam efeitos erga omnes automáticos. Ao mesmo tempo, em outras ocasiões, refuta a abstrativização. Vê-se, assim, que até mesmo na jurisprudência do Supremo encontramos posições contraditórias.

Decerto, a adoção da teoria da abstrativização, ainda que operada pelo constituinte reformador, importaria na assunção de alguns riscos, os quais, para muitos, jamais poderiam ser assumidos, em razão de patente violação a cláusulas pétreas. Para outros, apesar de atingir, em alguma medida, determinados princípios constitucionais (inclusive, cláusulas pétreas), a abstrativização não tocaria o núcleo essencial de qualquer deles. Por outro lado, potencializaria princípios como a isonomia e a segurança jurídica, além de promover a racionalização da jurisdição. 
O fato é que o tema está ainda longe de uma solução pacífica. Os debates ainda vêm sendo travados e é bom que assim ocorra, para que se evite, ao máximo, decisões legislativas ou jurisprudenciais precipitadas. Com efeito, qualquer passo dado em direção à consolidação da teoria da abstrativização deve ter suas consequências práticas muito bem estudadas e delimitadas, aferindo-se a sua real viabilidade diante do ordenamento constitucional brasileiro. 


\section{Bibliografia}

BARROSO, Luís Roberto. Curso de Direito Constitucional Contemporâneo: os conceitos fundamentais $e$ a construção do novo modelo. $3^{\mathrm{a}}$ ed. São Paulo: Saraiva, 2011.

O controle de constitucionalidade no

direito brasileiro. 6 ${ }^{a}$ ed. São Paulo: Saraiva, 2012.

CUNHA, Leonardo Carneiro da. A Fazenda Pública em juízo. 10ª ed. São Paulo: Dialética, 2012.

DEOCLECIANO, Pedro Rafael Malveira; SOUSA, José Péricles Pereira. A objetivação do controle difuso na ordem jurídica brasileira. Revista Direitos Fundamentais \& Democracia, UniBrasil - Faculdades Integradas do Brasil, $\quad$ v. $6, \quad 2009 . \quad$ Disponível em <http://www.revistaeletronicardfd.unibrasil.com.br>. Acesso em 15 de julho de 2012.

FUX, Luiz. Curso de direito processual civil, vol I, $3^{\mathrm{a}}$ ed., Rio de Janeiro: Forense, 2005.

GOMES, Luiz Flávio. Súmula Vinculante. Disponível em <http://www.mundojuridico.adv.br>. Acesso em 13 de julho de 2012.

JR. DIDIER, Fredie. Transformações do recurso extraordinário. In: WAMBIER, Teresa Arruda; JR. NERY, Nelson. Aspectos Polêmicos e Atuais dos Recursos Cíveis e Assuntos Afins, vol. 10, São Paulo: Revista dos Tribunais, 2006. 
LEITE, Fábio Carvalho. A cláusula da reserva de plenário segundo os Tribunais de Justiça. Custos Legis. Revista eletrônica do Ministério Público Federal. Disponível em < http://www.prrj.mpf.gov.br>. Acesso em 12 de julho de 2012.

LENZA, Pedro. Direito constitucional esquematizado. $13^{a}$ ed. São Paulo: Saraiva, 2009. O Senado é um mero menino de recado? Disponível em $<$ http://pedrolenza.blogspot.com.br/2011/05/o-senado-federal-e-um-meromenino-de.html>

MACEDO, Luana Vargas. Parecer PGFN/CRJ/N.492/2011. Revista da PGFN, Ano 1, Número 2. 2011. Disponível em <http://www.pgfn.fazenda.gov.br>. Acesso em 21 de julho de 2012.

MACHADO, Hugo de Brito. Ampliação do juízo de admissibilidade na apelação - Lei. 11.276. Revista Dialética de Direito Processual n. 38. São Paulo: Dialética, 2006.

MELlO, Patrícia Perrone Campos. Precedentes - $O$ desenvolvimento judicial do direito no constitucionalismo contemporâneo. Rio de Janeiro: Renovar, 2008.

MENDES, Gilmar Ferreira et al. Curso de Direito Constitucional. $4^{\mathrm{a}}$ ed. São Paulo: Saraiva, 2009.

- O papel do Senado Federal no Controle de Constitucionalidade: um caso clássico de mutação constitucional. Disponível em <http://www.direitopublico.idp.edu.br>. Acesso em 09 de julho de 2012. 
MORAIS, Dalton Santos. Crítica à caracterização da atuação senatorial no controle concreto de constitucionalidade brasileiro como função de publicidade. Revista Jus Navigandi. Disponível em <http://www.jus.com.br>. Acesso em 23 de julho de 2012.

RODRIGUES, Lays Faria. A Tendência da Abstrativização do Controle Difuso de Constitucionalidade. Disponível em <http://www.lfg.com.br>. Acesso em 11 de julho de 2012.

SILVA, José Afonso. Curso de Direito Constitucional Positivo. 27 ed. São Paulo: Malheiros Editores, 2006.

SOUZA, Eduardo Francisco de. A abstração do controle difuso de constitucionalidade. Revista Jurídica, Brasília, v. 9, n. 89, p.01-23, fev./mar, $\quad 2008 . \quad$ Disponível em $<$ http://www.presidencia.gov.br/revistajuridica>. Acesso em 15 de julho de 2012.

TAVARES, André Ramos. Curso de Direito Constitucional. $7^{\mathrm{a}}$ ed. São Paulo: Saraiva, 2009. - Perplexidades do Novo Instituto da Súmula Vinculante no Direito Brasileiro. Revista Eletrônica de Direito do Estado (REDE), Salvador, Instituto Brasileiro de Direito Público, $\mathrm{n}^{\mathbf{o}}$. 11, julho/agosto/setembro, $2007 . \quad$ Disponível em <http://www.direitodoestado.com>. Acesso em 13 de julho de 2012.

ZAVASCKI, Teori Albino. Eficácia das sentenças na jurisdição constitucional. Disponível em <http://www.lume.ufrgs.br〉. Acesso em 11 de julho de 2012. 
STRECK, Lênio Luiz et. al. A Nova Perspectiva do Supremo Tribunal Federal sobre o Controle Difuso: Mutação constitucional e Limites da Legitimidade da Jurisdição Constitucional. Disponível em <http://www.mundojuridico.com.br>. Acesso em 17 de julho de 2012.

$$
\text { O fahrenheit sumular do Brasil: o controle }
$$
panóptico da justiça. Disponível em <http://www.leniostreck.com.br>. Acesso em 13 de julho de 2012. 